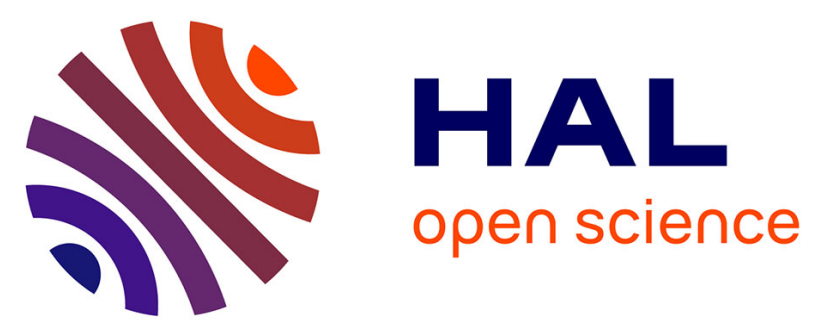

\title{
Dissolved organic matter released by two marine heterotrophic bacterial strains and its bioavailability for natural prokaryotic communities
}

Eva Ortega-Retuerta, Quentin Devresse, Jocelyne Caparros, Barbara Marie, Olivier Crispi, Philippe Catala, Fabien Joux, Ingrid Obernosterer

\section{To cite this version:}

Eva Ortega-Retuerta, Quentin Devresse, Jocelyne Caparros, Barbara Marie, Olivier Crispi, et al.. Dissolved organic matter released by two marine heterotrophic bacterial strains and its bioavailability for natural prokaryotic communities. Environmental Microbiology, 2020. hal-03007145

\section{HAL Id: hal-03007145 \\ https://hal.science/hal-03007145}

Submitted on 16 Nov 2020

HAL is a multi-disciplinary open access archive for the deposit and dissemination of scientific research documents, whether they are published or not. The documents may come from teaching and research institutions in France or abroad, or from public or private research centers.
L'archive ouverte pluridisciplinaire $\mathbf{H A L}$, est destinée au dépôt et à la diffusion de documents scientifiques de niveau recherche, publiés ou non, émanant des établissements d'enseignement et de recherche français ou étrangers, des laboratoires publics ou privés. 
1 Dissolved organic matter released by two marine heterotrophic bacterial strains

2 and its bioavailability for natural prokaryotic communities

3 Eva Ortega-Retuerta, Quentin Devresse*, Jocelyne Caparros, Barbara Marie, Olivier

4 Crispi, Philippe Catala, Fabien Joux, Ingrid Obernosterer

5 CNRS/Sorbonne Université, UMR7621 Laboratoire d'Océanographie Microbienne, Banyuls sur Mer, France

$6{ }^{*}$ Present address: Geomar Helmholtz Centre for Ocean Research Kiel, Germany

7

8 Running title: Bacterial DOM release and bioavailability 


\section{Originality-Significance Statement}

11 The role of heterotrophic prokaryotes as organic matter sources in the ocean is

12 increasingly receiving attention by the scientific community in view of its importance

13 for major biogeochemical fluxes, such as carbon sequestration via the "microbial carbon

14 pump". Here we present novel data on dissolved organic matter (DOM) production by

15 bacterial strains and how this bacterial-derived DOM is degraded by in situ prokaryotic

16 communities and how bacterial DOM shapes microbial metabolism and diversity. We

17 demonstrate that DOM quality produced by bacteria depends on their taxonomy, which

18 translates into different degradation mechanisms and the growth of different microbial

19 communities. Even though a high amount of bacterial derived DOM can be degraded

20 within days, this DOM source would lower the prokaryotic growth efficiency of

21 degrading microbial communities compared to in situ DOM. 


\section{Summary}

25 Marine heterotrophic prokaryotes (HP) play a key role in organic matter processing in oceans; however, the view of HP as dissolved organic matter (DOM) sources remains underexplored. In this study, we quantified and optically characterized the DOM produced by two single marine bacterial strains. We then tested the availability of these DOM sources to in situ Mediterranean Sea HP communities. Two bacterial strains were used: Photobacterium angustum (a copiotrophic gammaproteobacterium) and Sphingopyxis alaskensis (an oligotrophic alphaproteobacterium). When cultivated on glucose as the sole carbon source, the two strains released from 7 to $23 \%$ of initial glucose as bacterial derived DOM (B-DOM), the quality of which (as enrichment in humic or protein-like substances) differed between strains. B-DOM promoted significant growth and carbon consumption of natural HP communities, suggesting that it was partly labile. However, B-DOM consistently promoted lower prokaryotic growth efficiencies than in situ DOM. In addition, B-DOM changed HP exoenzymatic activities enhancing aminopeptidase activity when degrading $P$. angustum DOM, and alkaline phosphatase activity when using S. alaskensis DOM, and promoted differences in HP diversity and composition. DOM produced by HP affects in situ prokaryotic metabolism and diversity, thus changing the pathways for DOM cycling (e.g. respiration over biomass production) in the ocean.

44 Keywords: microbial carbon pump, dissolved organic matter, bioavailability, heterotrophic prokaryotes, prokaryotic diversity. 


\section{Introduction}

Heterotrophic prokaryotes (HP, bacteria and archaea) are key players in element cycling in the ocean. Roughly $50 \%$ of carbon that is fixed by primary production in the ocean is passing through HP (Azam et al., 1983), which can be respired into $\mathrm{CO}_{2}$ (HP respiration) or used to build up new biomass (HP production). The balance between these two processes, expressed as prokaryotic growth efficiency, is a key parameter to estimate carbon fluxes in the ocean and predict or model its changes (delGiorgio and Cole, 1998). However, it has been demonstrated that HP also release carbon in the form of dissolved organic matter (DOM). Pioneering studies showed that HP growing on simple substrates (i.e. glucose) could produce a myriad of different DOM compounds

57 (Stoderegger and Herndl, 1998; Ogawa et al., 2001; Kawasaki and Benner, 2006). Since then, numerous studies have attempted to characterize HP-derived DOM using analytical techniques such as ultra-high-resolution Fourier transform-ion cyclotron resonance-mass spectrometry (FT-ICR MS), high field nuclear magnetic resonance (NMR) or 3D fluorescence spectroscopy, demonstrating that HP successively process labile DOM and transform it into refractory DOM in an amount enough to sustain the whole oceanic refractory DOM pool (Catalá et al., 2015; Lechtenfeld et al., 2015; Osterholz et al., 2015). This process, termed the microbial carbon pump (MCP, (Jiao et al., 2010) is an important carbon sequestration mechanism. It has been estimated that carbon stored through the MCP accounts for $0.4 \%$ of primary production on a global scale; this is in the same range as carbon stored through sinking particulate organic matter ( 0.6 to $1.3 \%$ of primary production (Legendre et al., 2015)). HP release DOM as metabolic by-products or as a consequence of the uncoupling of anabolic and catabolic processes (Carlson et al., 2007). Since HP in the ocean exhibit a 
71 wide range of metabolisms, DOM compounds released to the media are expected to

72 differ among HP taxa, as demonstrated previously using experimental incubations

73 (Shimotori et al., 2012; Noriega-Ortega et al., 2019). HP also actively release DOM compounds for different processes such as polymer enzymatic cleaving (Smith et al., 1992), nutrient acquisition (e.g. siderophores for iron uptake (Andrews et al., 2003), cell-cell communication (e.g. homoseryl lactones for quorum sensing (Gram et al., 77 2002)) or toxins (Christie-Oleza et al., 2012). Thus, environmental variables could shape the quantity and quality of the DOM released, affecting DOM fluxes. Finally, DOM degradation in the ocean, including HP-derived DOM, could depend on the taxonomic composition of the DOM processing community (Teeling et al., 2012). To better understand and predict changes in carbon sequestration through the microbial carbon pump, accurate information about DOM production by heterotrophic prokaryotes and its cycling in the ocean is a priority. How HP-derived DOM is degraded and cycled, and which fraction of it would be respired to $\mathrm{CO}_{2}$ or would enter the oceanic refractory DOM pool, are questions that remain to be resolved. In this study, we aimed to evaluate the availability of DOM released by two single bacterial strains as a substrate for Mediterranean Sea heterotrophic prokaryotic communities. Our working hypotheses were (1) DOM quality differs among bacterial strains and (2) these differences in quality promote the growth of different prokaryotic communities, translated into different DOM degradation mechanisms.

91 To test these hypotheses, two step experiments were conducted: First, two single 92 bacterial strains with contrasting lifestyles and from different taxonomical classes (Photobacterium angustum and Sphingopyxis alaskensis) were axenically grown in minimum media with glucose as the only carbon source, and cultures were harvested at early stationary phase where DOM was extracted, quantified and characterized. Second, 
96 DOM derived from the strains was used as substrate for biodegradation experiments,

97 where in situ prokaryotic communities from the Mediterranean Sea were grown either

98 on in situ DOM or on the DOM produced by the two strains (Table 1, see experimental

99 procedures). In these experiments, changes in heterotrophic prokaryotic abundance were

100 followed together with changes in carbon and nutrients, exoenzyme activities and

101 prokaryotic community composition.

102 


\section{Bacterial strain growth: Glucose and nutrient consumption; BDOM production}

105

The two single strains used in the present study to produce bacterial-derived DOM exhibited contrasting patterns both in their growth rates and carrying capacities (Table 2, Suppl. Fig. 1): Photobacterium angustum grew fast (growth rates $1.1-1.5 \mathrm{~d}^{-1}$ ), this is, once the exponential growth started, the stationary phase was reached about $12 \mathrm{~h}$ later, with a cell abundance of around $5 \times 10^{6}$ cell $\mathrm{mL}^{-1}$ (Suppl. Fig. 1). Conversely, Sphingopyxis alaskensis grew slower (growth rates of 0.07-0.23 $\mathrm{d}^{-1}$ ), with a longer lagphase ( 3 to 5 days) but higher cell abundance (12 to $17 \times 10^{6}$ cell $\mathrm{mL}^{-1}$, Suppl. Fig. 1) when the stationary phase was achieved.

When cells and DOM were harvested, 12 to $17 \mu \mathrm{M}$ of carbon as glucose was remaining in the cultures (6-10\% of initial glucose concentrations, Fig. 1). However, there was 42 to $73 \mu \mathrm{M}$ of DOC remaining (Fig. 1). Comparing the decreases in glucose and in DOC at the beginning and at the end of the incubations (see Experimental Procedures), we estimated the amount of DOC that was produced by the bacterial strains. This DOC production was variable, ranging from $6.7 \%$ (S. alaskensis, March 2018$)$ to $22.8 \%(P$. angustum, March 2018) of the initial DOC. Bacteria passing through the filters represented less than $1 \%$ of cell abundances, and could only contribute to a tiny part of the DOC measured at the end of the cultures. No clear differences between strains could be observed in the \%DOC produced (Table 2). However, the two strains produced DOM of different quality. DOM produced by $P$. angustum was relatively more enriched in protein-like compounds (FDOM Peak T after Coble (1996), $34.3 \times 10^{-3}$ R.U. on average) as compared to DOM from S. alaskensis (8.9 $\times 10^{-3}$ R.U. on average). By contrast, all humic-like FDOM peaks were higher for S. alaskensis, in particular the M and A peaks that were twice as high as for P. angustum (Table 2). Regarding inorganic 
128 nutrients, both strains used preferentially $\mathrm{NH}_{4}$ over $\mathrm{NO}_{3}$, but significant amounts of $129 \mathrm{NH}_{4}, \mathrm{PO}_{4}$ and $\mathrm{NO}_{3}$ remained in the cultures at the end of the incubations 130 (Supplementary Table 1), indicating that carbon was the limiting substrate for the 131 bacterial growth.

132 Availability of bacterial-derived DOM for strain-derived natural heterotrophic prokaryotic communities

134

135

136

137

138

139

140

141

142

143

144

145

146

$147^{1}$ ), but although HP abundance was higher than that in the surface DOM treatment, it 148 was lower than HP abundances in the S. alaskensis DOM treatment (Suppl. Table 3).

149 We did not find significant differences in HP growth between treatments using $P$.

150

Biodegradation experiments: Changes in HP abundance, DOC and growth efficiency

DOM originating from the bacterial strains promoted remarkable HP growth in all biodegradation experiments (Fig. 2), with significant differences over time and between treatments in all three experiments (repeated measures ANOVA, $\mathrm{p}<0.05$, Suppl. Table 2). In the open sea-March biodegradation (Table 1), DOM from P. angustum supported a higher HP growth for surface and deep HP communities than their respective treatments with in situ DOM (Fig. 2a), although only significant for surface communities (Suppl. Table 3). In the coastal sea-April biodegradation experiment, differences in the HP abundances among treatments were only significant at certain timepoints (Fig. 2b, Suppl. Table 3). In the coastal sea-December biodegradation experiment, as in the open sea-March one, the treatments with bacterial DOM promoted significantly higher HP growth than in situ DOM (Fig. 2c, Suppl. Table 3). In the coastal sea-December experiment we included a treatment with glucose $(20 \mu \mathrm{mol} \mathrm{C} \mathrm{L}-$ angustum vs. S. alaskensis DOM (Suppl. Table 3). 
151 We performed controls in the degradation experiments, consisting of DOM from each

152 strain, with $\mathrm{N}$ and $\mathrm{P}$ additions similar to the treatments, but without inoculating with in situ HP communities. The purpose of these controls was to check for potential growth of the minimal amount of $P$. angustum and $S$. alaskensis cells that remained in the filtrates. Little cell growth was observed in these controls (Fig. 2a-c).

At the onset of the three biodegradation experiments, the DOC concentration was slightly different between treatments (Table 3). However, the amount of DOC consumed per hour (during the total incubation) was consistently higher in the treatments with strain derived DOM, except for coastal sea-April experiment Biodegradation experiment and S. alaskensis DOM (Table 3). Average DOC consumption in the incubations with strain DOM (both $P$. angustum and $S$. alaskensis DOM) was $0.30 \mu \mathrm{mol} \mathrm{L} \mathrm{L}^{-1} \mathrm{~h}^{-1}$, while in the treatments with in situ DOM, either deep or surface, the average was $0.08 \mu \mathrm{mol} \mathrm{L^{-1 }} \mathrm{h}^{-1}$. In the experiments with glucose additions the DOC consumption was on average $0.18 \mu \mathrm{mol} \mathrm{L} \mathrm{L}^{-1} \mathrm{~h}^{-1}$. When normalizing $\triangle \mathrm{DOC}$ by the initial DOC concentration in each treatment, these patterns were even more visible: $51 \%$ on average of the strain-derived DOC was degraded during the incubations, compared to $13.6 \%$ of in situ DOC (Table 3).

We further wanted to elucidate whether differences in HP growth were due to different initial amounts of DOC or to differences in its lability. For that purpose, we compared HP biomass changes with initial DOC concentrations in every treatment (Table 3). In contrast to total DOC utilization, we could not find consistent patterns in the relative amount of initial DOC incorporated into HP biomass (Table 3). The \%DOC invested into prokaryotic biomass was lower (open sea-March), similar (coastal sea-April) or higher (coastal sea-December) than in the in situ DOM (ndom) treatments. Comparing the treatments with P. angustum (pdom) or S. alaskensis (sdom), the changes in HP 
176 biomass compared to initial DOC were never significantly different. Interestingly,

177 prokaryotic growth efficiency (PGE) was consistently lower in treatments with strain-

178 derived DOM than in the treatments with in situ DOM in all biodegradation

179 experiments by a mean factor of 3.5 (range 1.3-7.0) (Fig. 3).

180 Biodegradation experiments: Changes in FDOM and inorganic nutrients

181 The different FDOM peaks did not decrease at the same level in every incubation

182 (Table 3): The peak T (surrogate of protein-like substances) tended to decrease up to a

$18370 \%$, while the FDOM at peak C (surrogate of humic-like compounds) tended to

184 increase in almost every experiment and treatment (Table 3). Humic-like peaks A and

$185 \mathrm{M}$ were more variable among experiments and treatments.

186 The inorganic nutrient concentrations, particularly those of $\mathrm{NO}_{3}{ }^{-}$, were also higher in 187 the treatments with bacterial-derived DOM as compared to the in situ DOM, since $P$.

188 angustum and S. alaskensis did not consume all inorganic nutrients during the previous 189 strain incubations and equivalent amounts of all inorganic nutrients were added to each 190 treatment of the biodegradation experiments. At the end of the incubations, substantial 191 amounts of all inorganic nutrients remained in all treatments (Supplementary Table 1).

192 Coastal biodegradation experiments: Changes in exoenzymatic activity

193 Differences in the predominant exoenzymatic activities could be observed between 194 treatments in Coastal sea-April and December experiments. In May, relatively high 195 alpha- and beta- glucosidase production rates were observed in the treatment with 196 surface DOM (Fig. 4 a,b) compared to the bacterial DOM treatments, but this result was 197 not visible in December (Fig. 4 e,f). Remarkably, in both biodegradation experiments $P$. 198 angustum DOM induced high rates of leucine aminopeptidase (Fig. $4 \mathrm{c}$ and g), while the 199 S. alaskensis DOM always induced high rates of alkaline phosphatase (Fig. $4 \mathrm{~d}$ and h). 

composition

202 Changes in HP diversity and community composition along the incubations were detected in all treatments and replicates of Coastal sea-December experiment, the only experiment where these samples were taken. A decrease in diversity between the onset and end of the incubations, expressed as richness, evenness or Shannon diversity, was detected in all treatments. Significant differences between treatments were observed at tf (ANOVA, $\mathrm{p}<0.001$ for all richness, evenness and Shannon). HP communities growing on surface DOM had higher richness, evenness and Shannon than the communities growing on bacterial-derived DOM (Table 4).

210 At the onset of the experiments, the HP community was distributed among different orders, with Alphaproteobacteria (groups of SAR11, Rhodobacterales and

212 Rhodospirilalles), SAR86 (Gammaproteobacteria) and Flavobacteriales as the most 213 abundant groups (Fig. 5). At the end of the incubations, differences between treatments 214 could be detected (ANOSIM test, $\mathrm{p}<0.05$ ): The surface DOM treatment was 215 dominated by Alteromonadales, Flavobacteriales and SAR86, the surface DOM $216+$ glucose was dominated by Vibrionales and Flavobacteriales (except for replicate 3 217 where Oceanospirilalles were comparatively more abundant), the P. angustum DOM treatments were dominated by Alteromonadales, Rhodobacterales, Flavobacteriales (but

219 replicate 2 showed a potential contamination by Campylobacter) and the S. alaskensis 220 DOM treatment was dominated by Vibrionales, with more than half of the sequences corresponding to this order, but also Rhodospirilalles. A MDS ordination based on Bray

222 Curtis similarities showed separation among treatments with replicates grouping 223 together, illustrating the significant differences (ANOSIM test, $\mathrm{p}<0.05$ ) in HP structure 224 (Fig. 5). 


\section{Comparison of DOC release rates among studies (strains vs in situ communities)}

227 The bacterial DOC release rates reported here (7 to $23 \%$ of initial DOC, average $12 \%$ ) 228 are within those previously published for mixed/natural communities $(3.5-22 \%)$ but 229 higher than the four published studies using single bacterial strains $(3.7 \%$ on average, 230 Table 5). All previously published studies using single strains used 5 to 350 times higher initial DOC concentrations than in the present study, and some only quantified the DOM retained by solid-phase cartridges (Romano et al., 2014) or only the DOM released as extracellular polysaccharide (Zhang et al., 2015), making the values lower. The only study measuring DOC production by Archaea through chemoautotrophy also reported DOM release within our ranges when looking at DOM produced vs. biomass produced (Bayer et al., 2019). We could expect that the net DOM production by natural communities would be lower than the ones recorded using single strains, since DOM produced by some HP groups could be consumed by others. However, our DOM production values were within the range of previous studies using mixed communities (i.e., 3.5-22\%, Table 5). The DOM production values obtained in our strain incubations could be conservative estimates. On one hand, the method used to quantify glucose (Myklestad et al. 1997) also determines other dissolved monosaccharides. Although it is very unlikely that the strains would have released these compounds without making use of them, their potential presence would lead to an underestimation of the DOM release rates in our experiments. On the other hand, HP release DOM not only as metabolic byproducts, but also with functional roles such as cell-signaling (Gram et al., 2002) or particle degradation (Smith et al., 1992) among many others, processes that would not be happening in our simple glucose-amended monocultures, so DOM production in situ by HP would likely be higher than the calculated in our study. For instance, substrate 
250

251

252

253

254

255

256

257

258

259

260

261

262

263

264

265

266

267

268

269

270

271

272

273

274

quality is likely crucial determining the quantity and quality of DOM produced: Ogawa et. al. (2001) and Wienhausen et. al. (2017) showed higher release of dissolved amino acids by heterotrophic bacterial strains when growing on glutamate than when growing on glucose, even though the amino acid composition was similar among treatments. If grown on complex substrates, their enzymatic degradation would likely enhance the release of DOM by HP (Aparicio et al., 2015). Further work is needed to explore which would be the main nutritional drivers, e.g. going beyond glucose amendments to testing the effect of the DOM source, of DOM production by HP in the sea.

\section{Quantity and quality of bacterial DOM}

Even though the quantity of DOM released by our two study strains was similar, we could evidence clear differences in its fluorescence signature, which suggests different chemical composition. The production of protein-like FDOM observed for P. angustum in the present study, has been previously reported for Alteromonas macleodii when grown on glucose (Goto et al., 2017) and for mixed bacterial communities grown on phytoplankton exudates (Romera-Castillo et al., 2011) or on lake water (Cammack et al., 2004). By contrast, the low protein-like FDOM signature in S. alaskensis DOM illustrates the importance of bacterial taxonomy for bacterial FDOM quality. $P$. angustum (our study) and A. macleodii (Goto et al., 2017) are both fast-growing copiotrophic bacteria, suggesting a link between aspects of bacterial metabolism and protein-like FDOM release. This is in line with the fact that copiotrophs have a higher number of secreted proteins than oligotrophs (Lauro et al., 2009), thus the quantity and composition of the secreted DOM would be likely dependent on the expression and production of these proteins. The production of humic-like DOM by bacteria has been shown using single strains (Shimotori et al., 2012) and experimental incubations with mixed communities (Rochelle-Newall and Fisher, 2002; Romera-Castillo et al., 2011). 
275 Humic-like FDOM (peaks A, C and M) is released to the ambient seawater as a 276 byproduct of organic matter remineralization by HP, and has been used as a tracer for 277 refractory DOM in the ocean (Yamashita and Tanoue, 2008; Catalá et al., 2015).

278 Therefore, we hypothesized that DOM produced by S. alaskensis, more rich in humic-

279 like compounds, would be less available for HP degradation in our experiments.

280 Few previous published studies have tested bacterial-DOM degradation by in situ HP communities. Both Kramer and Herndl (2004) and Zhang et al. (2015), these latter authors only using the exopolysaccharide fraction of bacterial DOM, concluded that DOM derived from mixed communities was mostly refractory, since no significant growth was detected during 2 to 14 days. However, Lønborg et al. (2009) followed DOC changes over longer time periods (30 d), and concluded that at least a fraction of HP-derived DOM can be utilized by other prokaryotic communities, indicating that HPDOM is semilabile. This is in accordance with our results, showing that $51 \%$ of organic carbon produced by the strains was further used by in situ HP communities (Table 3).

\section{Influence of HP community composition for the degradation of bacterial DOM}

In contrast to our hypothesis, differences in the lability of $P$. angustum vs. $S$. alaskensis

DOM could not be demonstrated by our biodegradation experiments, as inverse growth patterns on the two strain-derived DOM treatments were observed between coastal communities from April and December (Fig. 2). This suggests that not only the quality of the bacterial DOM, but also the in situ HP community composition would affect bacterial DOM degradation, as previously shown (Nelson and Wear, 2014). Our study strains released DOM that could not be used by themselves, since little bacterial growth of the residual cells was observed even when reinoculating with inorganic nutrients (control treatments in biodegradation experiments, Fig. 2), although this could be due to the possible damage of those cells after freezing. Whether the bacterial DOM can be 
degraded by single strains, as shown for labile in situ DOM and Alteromonas macleodii

301 (Pedler et al., 2014), or whether the complementary metabolic strategies of a diverse

302

303

304

305

306

307

308 community are required, remains to be investigated. The remarkable growth of in situ HP communities was not only due to the glucose that remained in the pdom and sdom treatments, since HP abundance was in both cases higher than in the +glucose treatment. A possibility that we cannot exclude is that this remaining glucose boosted the utilization of other substrates. Differences in HP growth among experiments can be explained not only by differences in the in situ communities but also by in situ DOM variability: In late spring in the Mediterranean Sea, DOM is usually enriched in labile compounds after the spring phytoplankton bloom (Jones et. al., 2013, Ortega-Retuerta et. al., 2018), so the in situ DOM was likely more labile than bacterial derived DOM, in contrast to December, when DOM can have other signatures (i.e. terrestrial-like, Sanchez-Pérez et. al., 2020).

In fact, despite non-significant differences in HP growth, consistent patterns of exoenzyme activity were detected: $P$. angustum DOM always promoted high leucineaminopeptidase activity rates (Fig. 4), in line with its relative enrichment in protein-like FDOM compounds (Table 2). By contrast, S. alaskensis DOM consistently promoted relatively high levels of alkaline phosphatase (Fig. 4). This last result was intriguing to us, since inorganic phosphorus was added at the beginning of each biodegradation experiments and thus HP communities were not P-limited. Although high alkaline phosphatase activities have been traditionally interpreted as P limitation (Cotner et al., 1997; Thingstad et al., 1998), HP can use these exoenzymes to release available dissolved organic carbon, as pointed out by previous studies (Benitez-Nelson and Buesseler, 1999; Van Wambeke et al., 2002). Our results suggest that S. alaskensis DOM could be rich in phosphorus-containing groups. We could see (only in the coastal 
325 December experiment) that the S. alaskensis DOM treatment was the one with a higher proportion of Rhodospirilalles. This order has been found in P-limited ocean areas

327 linked to the presence of the carbon-phosphorus lyase pathway for phosphonate

328 degradation (Sosa et al., 2019), in accordance with our hypothesis of P-rich DOM 329 produced by S. alaskensis.

330 Bacterial DOM sustained a lower HP diversity as compared to the in situ DOM (Table 331 4). In line with this, Noriega-Ortega et al. (2019) compared the solid- phase extractable 332 DOM produced by single bacterial strains with that of marine DOM from the North 333 Pacific and observed higher diversity of compounds in marine DOM respect to 334 bacterial-derived DOM. HP strains were shown to produce thousands of DOM 335 molecules when using a single carbon substrate, however, the DOM chemical diversity 336 produced by a single bacterium with respect to DOM from coastal seawater is likely to 337 be lower. In any case, the significant differences in community composition between treatments suggest population-specific responses to the differences in quality of the

339 DOM produced by P. angustum and S. alaskensis.

340 Bacterial DOM, PGE and carbon fluxes

341 The growth on strain-derived DOM induced significantly lower prokaryotic growth 342 efficiency (PGE). To the best of our knowledge, our study provides the first 343 measurements of PGE on bacterial-derived DOM, demonstrating that bacterial DOM is 344 preferentially respired. HP do not only promote DOC accumulation in the ocean 345 through the production of refractory DOM (the microbial carbon pump hypothesis 346 shown in previous studies), but would also enhance carbon remineralization (therefore, 347 acting as a $\mathrm{CO}_{2}$ source). Noteworthy, we did not include DOM production by natural 348 HP communities in our PGE calculations in the biodegradation experiments, and 
including DOM production in our calculations would lead to even lower PGE values in all treatments.

\section{Changing the paradigm of carbon fluxes through HP in the ocean}

352 DOM release by HP has been repeatedly demonstrated, however, carbon (and other 353 elements) release by HP as DOM is still overlooked when constraining carbon budgets 354 or other elemental fluxes and models in the ocean. For instance, considering that HP 355 produce, on average, $10 \%$ of DOC as DOM (average from values in Table 5), in situ HP 356 production estimates (e.g. using isotopes incorporation such as ${ }^{3} \mathrm{H}$-leucine, (Kirchman et 357 al., 1985) would be underestimated. To better constrain this uncertainty, it is important 358 to know whether DOM release is linearly related to HP biomass production during short 359 incubation times. The release of DOM would also affect estimates of HP growth 360 efficiency. Prokaryotic carbon demand can be calculated as the sum of HP biomass production and respiration or as differences in DOC concentrations in bottle incubations (the dilution approach (delGiorgio and Cole, 1998)), but in both cases PGE would be overestimated by roughly $10 \%$, according to published results. The overestimation could even be higher if, as demonstrated in our study, this $10 \%$ of DOM produced by HP would enhance respiration over biomass production. More studies are needed to better understand the dynamics of DOM production by HP and their drivers, and therefore to constrain carbon fluxes through HP.

\section{Conclusion and perspectives}

370 In this study, we demonstrate that two marine heterotrophic bacterial strains growing on

371 glucose release remarkable amounts of DOM (compared with biomass production), and

372 that an important fraction of this bacterial derived DOM is available for Mediterranean 373 Sea HP communities. Should this pattern be observed globally, the production of DOM 
374 by prokaryotes in the sea would change carbon fluxes through HP towards a decrease in

375 prokaryotic growth efficiency, as well as shaping HP community and exoenzyme

376 activities. While in the present study DOM release is measured in single strains growing

377 on glucose, the uptake of other organic compounds will likely affect the quantity and

378 lability of the released DOM, hence affecting further metabolisms in the ocean. Further

379 work is needed to better constrain the main mechanisms affecting HP DOM production

380 and degradation in the ocean, thus improving our knowledge on carbon sequestration

381 processes such as the microbial carbon pump.

\section{$382 \quad$ Experimental procedures}

\section{Bacterial strains growth}

384 In order to get dissolved organic matter (DOM) produced by marine bacteria, we grew axenically two strains with contrasting ecology and different taxonomical classes: The first one, Photobacterium angustum S14, is a Gammaproteobacterium (Vibrionales, Vibrionaceae) which was isolated from coastal waters (Humphrey et al., 1983). The second strain, Sphingopyxis alaskensis RB2256 (Sphingomonoadales, Sphingomonadaceae), is an Alphaproteobacterium isolated from open waters in the North Pacific Ocean (Eguchi et al., 2001). These bacterial strains can be considered as models of copiotrophic (P. angustum) and oligotrophic (S. alaskensis) life styles (Lauro et al., 2009). The strains were selected based on their capacity to grow on glucose and the laboratory's experience in culturing them (Matallana-Surget et al., 2009; Koedooder et al., 2018). Both strains were preserved in glycerol at $-80^{\circ} \mathrm{C}$. The stocks were thawed and grown in minimum media, modified from Fegatella et al. (1998), composed of artificial seawater (salinity 35$)$ with glucose as the sole carbon source $(\approx 200 \mu \mathrm{M} \mathrm{C}$ ),

397 nitrogen (50:50 mixture of $\mathrm{NH}_{4} \mathrm{Cl}$ and $\left.\mathrm{NO}_{3}\right)$ and phosphorus $\left(\mathrm{NaHPO}_{4}\right)$ at a $\mathrm{C}: \mathrm{N}: \mathrm{P}$ ratio 
of 45:9:1, equivalent to the internal stoichiometry of bacterial cells (Goldman et al.,

399 1987), and trace amounts of metals and vitamins. In order to minimize the presence of 400 glycerol in the media and get the cells adapted to the growth conditions, two 401 acclimation steps were made, where cells were diluted on fresh media (initial 402 concentration $\approx 10^{4}$ cell $\mathrm{mL}^{-1}$ ) and grown to $1-2 \times 10^{6}$ cell $\mathrm{mL}^{-1}$. Purity of the cultures 403 was controlled at each step by plating samples on Marine Agar. Experimental 404 incubations were set up in triplicate in $500 \mathrm{~mL}$ flasks, with two contamination controls, consisting of flasks containing culture media but without bacterial inoculation. Incubations were performed at $25^{\circ} \mathrm{C}$ with rotary agitation $(90 \mathrm{rpm})$ until the stationary 407 phase was reached (controlled several times per day by flow cytometry). No bacterial 408 growth was detected in the contamination controls. Once the stationary phased was 409 reached, the DOM was harvested by gentle filtration through pre-rinsed (Milli-Q water, $410250 \mathrm{~mL}) 0.2 \mu \mathrm{m}$ polycarbonate filters using an all-glass filtration system. All glass 411 material used for the incubations and filtrations was previously combusted $\left(450^{\circ} \mathrm{C}, 5 \mathrm{~h}\right)$.

412 Previous tests (dissolved organic carbon concentration and DOM fluorescence 413 measurements on Milli-Q water filtered using the same device and filters) showed 414 insignificant DOM leaching from the polycarbonate filters (data not shown). In the 415 DOM filtrates, samples for glucose, dissolved organic carbon (DOC), inorganic 416 nutrients, DOM fluorescence and flow cytometry (to check for the presence of cells 417 passing through the filters) were taken, and the remaining DOM was kept at $-20^{\circ} \mathrm{C}$ 418 before being used as substrates for biodegradation experiments (see below). We chose 419 to sample in the early stationary phase to ensure that minimal amounts of glucose were 420 remaining in the DOM extracts for the biodegradation experiments, although at this 421 stage some of the bacterial DOM could derive from cell lysis. Strain cultures p1 and s1 422 (Fig. 1) were used for the biodegradation experiments 1 and 2, while strain cultures p2 
and s2 were used for biodegradation experiment 3. Being aware that freezing could alter some DOM properties, we chose this preservation method due to the inability to perform the biodegradation experiments shortly after the strain incubations were finished.

\section{Biodegradation experiments}

428 To study how DOM derived from the bacterial strains is degraded by natural marine 429 heterotrophic prokaryotic (HP) communities, re-growth cultures were performed (Table 1). These consisted of $10 \%$ dilutions of natural HP communities from different NW Mediterranean Sea locations (water prefiltered by $0.8 \mu \mathrm{m}$ to remove most 432 phytoplankton and grazers) with $90 \%$ DOM $(0.2 \mu \mathrm{m}$ filtrates $)$ from the following 433 sources: DOM sampled from the same waters as the HP communities (in situ surface or deep DOM, ndom treatments) or DOM harvested from the strain cultures explained above: Photobacterium angustum ( $P$. angustum DOM treatments, pdom) or Sphingopyxis alaskensis (S. alaskensis DOM treatments, sdom). DOM for ndom

437 treatments was prepared by filtering seawater from the same location as the prokaryotic 438 innocula through $0.2 \mu \mathrm{m}$ filters as for the bacterial DOM. Inorganic nutrients (nitrogen 439 (50:50 mixture of $\mathrm{NH}_{4} \mathrm{Cl}$ and $\left.\mathrm{NO}_{3}\right)$ and phosphorus $\left(\mathrm{NaHPO}_{4}\right)$, final concentrations in supplementary Table 1) were added to each treatment to force carbon limitation, and all treatments were set up in triplicate in $250 \mathrm{~mL}$ flasks. Incubations were performed at $44218^{\circ} \mathrm{C}$ in the dark for 7-8 days.

443 Using this approach, we performed three different experiments: Open sea-March experiment: We selected waters from a station located on the edge of the continental shelf (hereafter termed as "open sea") in the North Western Mediterranean Sea $\left(42^{\circ} 27^{`} 205 \mathrm{~N}-03^{\circ} 32^{\prime} 565 \mathrm{E}, 600 \mathrm{~m}\right.$ depth) at two different depths: 5m (surface

447 communities) and 500m (deep communities), in March 2018. These natural HP 
449 DOM, with the purpose to evaluate the differences in HP growth depending on the 450 initial community (surface vs. deep marine communities). For this experiment, samples

451 for DOC, FDOM and nutrients were taken at the onset and end of the incubations, while 452 HP abundance was monitored daily by flow cytometry. For the Coastal sea-April 453 experiment, we collected surface waters from a coastal station $\left(42^{\circ} 29^{\prime} 3 \mathrm{~N}, 3^{\circ} 8^{\prime} 7 \mathrm{E}, 20 \mathrm{~m}\right.$ 454 bottom depth) in April 2018 and grew HP communities on in situ DOM, DOM 455 produced by $P$. angustum, and DOM produced by $S$. alaskensis, to evaluate growth of 456 the same HP community on different DOM sources. In this experiment, we monitored 457 the same variables as in Open sea-April experiment and, in addition, we measured the 458 exoenzyme activity at the onset, day 3, and end of the experiment. For the Coastal sea459 December experiment, we collected surface waters from the same coastal station as for 460 biodegradation Experiment 2 (42.29'3N, 3'8'7E, 20m depth), but in December 2018.

461 The treatments were the same as in May 2018 and thus allowed us to investigate 462 seasonal differences. We included an additional "+Gluc" treatment to evaluate the effect 463 of residual glucose amounts in the bacterial DOM sources. In this last experiment, we 464 monitored the same variables as in biodegradation experiment 2 (DOM, nutrients, HP 465 abundance and exoenzyme activities) and, additionally, we measured the HP 466 community structure (16s rRNA Illumina sequencing) at the onset and end of the 467 experiment.

\section{Chemical and biological analyses}

Dissolved organic carbon (DOC)

470 Samples $(10 \mathrm{~mL})$ for DOC were transferred into precombusted glass tubes, acidified 471 with $85 \% \mathrm{H}_{3} \mathrm{PO}_{4}$ (final $\mathrm{pH}$ 2), closed with Teflon lined screw caps and stored in the 
472 dark at room temperature until analysis (less than 2 months after sampling). Calibration

473 curves were made using an acetanilide solution $\left(\mathrm{C}_{8} \mathrm{H}_{9} \mathrm{NO} ; \mathrm{M}=135.17 \mathrm{~g} \mathrm{~mol}^{-1}\right)$. DOC

474 was analysed using the high temperature catalytic oxidation (HTCO) technique (Benner

475 and Strom, 1993) with a Shimadzu TOC-V-CSH analyser. Standards of 44-45 $\mu \mathrm{mol} \mathrm{C}$

$476 \mathrm{~L}^{-1}$, provided by D.A. Hansell and Wenhao Chen (Univ. of Miami), were used to assess

477 the accuracy of the measurements.

478 Glucose

479 Glucose was quantified using a modification of the colorimetric protocol described by 480 Myklestad et al. (1997). Samples $(200 \mu \mathrm{L})$ were stored in pre-combusted glass vials at $48120^{\circ} \mathrm{C}$ until analysis. All reagents were downscaled to $200 \mu \mathrm{L}$ samples, and incubations 482 after reagent $\mathrm{A}$ additions were performed during $20 \mathrm{~min}$ in a $100^{\circ} \mathrm{C}$ water bath. The 483 reagents were calibrated daily using a standard curve made of D-glucose in the same 484 batch of artificial seawater used for the strain incubations. Milli-Q water and artificial 485 sea water blanks were run daily in triplicate. Glucose concentrations in $\mu$ mol were 486 converted in carbon equivalent (C-Glucose).

FDOM samples were freshly (within 1-3 h) analyzed with a Perkin Elmer luminescence spectrometer LS 55 equipped with a xenon discharge lamp, equivalent to $20 \mathrm{~kW}$. Slit 490 widths were $10.0 \mathrm{~nm}$ for the wavelengths of excitation and emission. We characterized 4914 groups of fluorophores using the following excitation/emission (ex/em) pairs (Coble, 1996): $280 \mathrm{~nm} / 350 \mathrm{~nm}$ (peak T, surrogate of protein-like substances); $250 \mathrm{~nm} / 435 \mathrm{~nm}$ (peak A); $340 \mathrm{~nm} / 440 \mathrm{~nm}$ (peak C) and $320 \mathrm{~nm} / 410 \mathrm{~nm}$ (peak M) the later three due to 494 humic substances of different origins (Coble, 1996). Fluorescence intensities of the 495 peaks were reported in Raman units (R.U.) obtained by dividing the fluorescence units 
by the Milli-Q blank peak area (Raman scatter) excited at $350 \mathrm{~nm}$.

497

498

499

500

501

502

503

504

505

506

507

508

509

510

511

512

513

514

515

516

517 Each sample was pipetted in triplicate into 96-well black plates with the following 518

\section{Dissolved inorganic nutrients}

Samples for inorganic nutrient analyses were kept frozen at $-20^{\circ} \mathrm{C} . \mathrm{NO}_{3}+\mathrm{NO}_{2}$, and $\mathrm{PO}_{4}$ were quantified with a segmented flow analyser (Bran Luebbe) with colorimetric detection using methods described in Holmes (1999). The accuracy of the methods was assessed using reference material (Certipur, Merck). The precisions were in the range of $1-4 \%$, and the detection limits were $0.02 \mu \mathrm{M}$ for $\mathrm{NO}_{3}+\mathrm{NO}_{2}$, and $0.03 \mu \mathrm{M}$ for $\mathrm{PO}_{4} . \mathrm{NH}_{4}$ samples were collected into pre-rinsed $20 \mathrm{~mL}$ HDPE bottles and stored frozen at $-20^{\circ} \mathrm{C}$ before being analysed by fluorometric detection (Holmes, 1999).

\section{Bacterial and heterotrophic prokaryotic abundance}

Cell abundances in all experiments were monitored by flow cytometry. Subsamples were fixed with glutaraldehyde $(0.5 \%$ final concentration $)$ and preserved at $-80^{\circ} \mathrm{C}$ prior to analysis (within days). Cell abundance was measured by using Beckman CytoFLEX and BD FACSCanto flow cytometers equipped with lasers exciting at $488 \mathrm{~nm}$. Samples were thawed and stained with SYBR Green $(0.025 \%(\mathrm{v} / \mathrm{v})$ final concentration). Fluorescent beads $(1 \mu \mathrm{m})$ were added as internal standards. Samples were run at low speed (10 to $16 \mu \mathrm{L} \mathrm{min}^{-1}$ ) for 60 to 90 seconds. Prokaryote communities were identified in plots of side scattered light vs. green fluorescence (del Giorgio et al., 1996).

\section{Extracellular enzyme activities}

Extracellular enzyme activities were quantified with the use of fluorogenic substrates (Hoppe, 1983) with the modifications for plate readers described in Sala et al. (2016). substrates: 4-methylumbelliferyl $\quad$-D-glucopyranoside (for $\quad$-glucosidase), 4- 
methylumbelliferyl $\alpha$-D-glucopyranoside (for $\alpha$-glucosidase), 4-methylumbelliferyl

520 phosphate (for alkaline phosphatase), and L-leucine-7-amido-4-methyl coumarin (for

521 leu-aminopeptidase) added (final concentration $120 \mu \mathrm{mol} \mathrm{L} \mathrm{L}^{-1}$ ). Fluorescence was

522 measured immediately after addition of the substrate and after incubations (up to $5 \mathrm{~h}$

523 with one middle timepoint) in the dark at the same temperature as for the experimental

524 incubations. Fluorescence readings were done with a Victor3 Perkin Elmer

525 spectrofluorometer at 355/450 nm ex/em wavelengths. The increase of fluorescence

526 units during the period of incubation was converted into enzymatic activity with a

527 standard curve prepared with the end products of the reactions, 7-amido-4-

528 methylcoumarin (MCA) for leu-aminopeptidase and 4-methylumbelliferone (MUF) for

529 the rest of enzymes.

530

531

532

533

534

535

536

537

538 lysozyme solution ( $36 \mathrm{mg} \mathrm{mL}^{-1}$ ), and a second incubation at $55{ }^{\circ} \mathrm{C}$ for $1 \mathrm{~h}$ after adding

$53980 \mu \mathrm{L}$ of $10 \%$ sodium dodecyl sulfate and $8 \mu \mathrm{L}$ of proteinase $\mathrm{K}\left(20 \mathrm{mg} \mathrm{mL}^{-1}\right)$. After

540 denaturation and degradation of proteins, DNA was purified using a Quick-DNA ${ }^{\mathrm{TM}}$

541 fungal/bacteria miniprep kit (Zymo Research, Catalog No. D6005) according to the

542 manufacturer's instructions. 
543 The V4-V5 region of the 16S rRNA gene from both fractions was amplified with the

544 primer sets 515F-Y (5'-GTGYCAGCMGCCGCGGTAA) and 926-R (5'545 CCGYCAATTYMTTTRAGTTT) as described in Parada et al. (2016) with a 546 modification to the PCR amplification step. Triplicate $20 \mu \mathrm{L}$ reaction mixtures contained $5472 \mu \mathrm{g}$ DNA, $5 \mu \mathrm{l} \mathrm{KAPA2G}$ Fast HotStart ReadyMix, $0.2 \mu \mathrm{M}$ forward primer and $0.2 \mu \mathrm{M}$ 548 reverse primer. Cycling reaction started with a 3 min heating step at $95^{\circ} \mathrm{C}$ followed by 54930 cycles of $95^{\circ} \mathrm{C}$ for $45 \mathrm{~s}, 50^{\circ} \mathrm{C}$ for $45 \mathrm{~s}, 68^{\circ} \mathrm{C}$ for $90 \mathrm{~s}$, and a final extension of $68^{\circ} \mathrm{C}$ 550 for $5 \mathrm{~min}$. The presence of amplification products was confirmed by $1 \%$ agarose 551 electrophoresis and triplicate reactions were pooled. The pooled PCR amplicons were 552 purified using Sephadex G-50 Superfine resin (GE Healthcare Bio-Sciences, New 553 Jersey, USA) following the protocol. The purification step aims to desalt the samples 554 and eliminate unincorporated nucleotides and excess PCR primers. 16S rRNA gene 555 amplicons were sequenced with Illumina MiSeq $2 \times 250$ bp chemistry on one flow-cell 556 at GeT-PlaGe platform (Toulouse, France). A mock community DNA (LGC standards, 557 UK) was used as a standard for subsequent analyses and considered as a DNA sample 558 for all treatments.

559 All samples from the sequencing run were demultiplexed by GeT-PlaGe and barcodes 560 were trimmed off. Processing of sequences was performed using the DADA2 pipeline 561 (version 1.10) (Callahan et al., 2016) in R (version 3.4.2) with following parameters: 562 trimLeft $=c(19,20)$, truncLen $=c(240,200), \operatorname{maxN}=0, \operatorname{maxEE}=c(2,2)$, truncQ $=2$. Briefly, 563 the pipeline combines the following steps: filtering and trimming, dereplication, sample 564 inference, chimera identification, and merging of paired-end reads. It provides exact 565 amplicon sequence variants (ASVs) from sequencing data with one nucleotide 566 difference instead of building operational taxonomic units (OTUs) based on sequence 567 similarity. ASVs were assigned against SILVA release 132 database (Quast et al., 
2013). Singletons and sequences assigned to chloroplast and mitochondria were

569

570

571

\section{Data analyses}

573 In the strain incubations, we calculated the \% of initial DOC transformed to bacterial-

574 derived DOM (\%DOC) as the difference between final carbon as glucose (C-Glucose)

576

577

578

579

580

581

582

583

584

585

586

587

588

589

590

591

592 and dissolved organic carbon (DOC) along the incubations as follows:

$$
\% D O C=\frac{\text { DOC }_{\mathrm{tf}}\left(\mu \mathrm{mol} \mathrm{L}^{-1}\right)-\mathrm{C}-\mathrm{Glucose}_{\mathrm{tf}}\left(\mu \mathrm{mol} \mathrm{L}^{-1}\right)}{\mathrm{DOC}_{\mathrm{to}}\left(\mu \mathrm{mol} \mathrm{L}^{-1}\right)}
$$

This equation would be applicable only if at t0, DOC and glucose values were equal. However, there were slight differences between these two pools at t0 in the $S$. alaskensis cultures s1 and s2 (Fig. 1). Because glucose was the sole organic carbon source added to the cultures (final concentration of $200 \mu \mathrm{M} \mathrm{C}$-glucose), the difference is likely due to the introduction of DOC contamination while manipulating the cultures, or due to analytical differences between the glucose and DOC analyses.

Thus, we decided to consider this initial DOC excess (DOC(t0)-C-glucose $(\mathrm{t} 0)$ ) as a nonreactive pool and subtract it from the concentrations at the beginning and end of each incubation. This is the most conservative way to calculate the $\% \mathrm{DOC}$ released as DOM by the strains, since, alternatively, the strains could have taken up some of this extra DOC and then released a fraction of it back as bacterial DOM.

Prokaryotic growth efficiency (PGE) in the biodegradation experiments was calculated as the increase in cell biomass between t0 and tf divided by the decrease in DOC between $\mathrm{t} 0$ and $\mathrm{tf}$ in the incubations using this formula:

$$
\operatorname{PGE}(\%)=\frac{\Delta \operatorname{Biomass}\left(\mu \mathrm{mol} \mathrm{L}^{-1}\right)}{\Delta \operatorname{DOC}\left(\mu \mathrm{mol} \mathrm{L}^{-1}\right)} \times 100
$$

using a general cell to biomass conversion factor of $20 \mathrm{fg} \mathrm{cell}^{-1}$ (Watson et al., 1977 ). 
593 Differences in HP abundance between treatments in the biodegradation experiments

594 were tested using repeated measures ANOVA and post-hoc pairwise t-tests (package

595 "rstatix" in R). Differences in prokaryotic community structure were tested by

596 ANOSIM tests (package "vegan" in R).

\section{Acknowledgements}

598 This work was supported by the Caramba project (European commission, H2020599 MSCA-IF-2015-703991). Flow cytometric analyses were performed at the BioPic 600 cytometry and imaging platform (Sorbonne University/CNRS). DNA extractions and 601 PCR amplifications were conducted at the Bio2Mar platform (Sorbonne 602 University/CNRS). Dr. Yan Liu kindly provided assistance in PCR and DNA cleaning 603 steps as well as in sequence processing. The 16 s samples were sequenced in the INRAE 604 platform. We thank the crew of $\mathrm{R} / \mathrm{V}$ 'Nereis II' and the technicians of the Banyuls 605 observation service for their assistance in getting Mediterranean Sea samples for the 606 biodegradation experiments.

\section{References}

608 Andrews, S.C., Robinson, A.K., and Rodríguez-Quiñones, F. (2003) Bacterial iron 609 homeostasis. FEMS Microbiology Reviews 27: 215-237.

610 Aparicio, F.L., Nieto-Cid, M., Borrull, E., Romero, E., Stedmon, C.A., Sala, M.M. et al.

611 (2015) Microbially-mediated fluorescent organic matter transformations in the deep

612 ocean. Do the chemical precursors matter? Frontiers in Marine Science 2.

613 Azam, F., Fenchel, T., Field, J.G., Gray, J.S., Meyerreil, L.A., and Thingstad, F. (1983)

614 The ecological role of water-column microbes in the sea. Marine Ecology-Progress 615 Series 10: 257-263.

616 Bayer, B., Hansman, R.L., Bittner, M.J., Noriega-Ortega, B.E., Niggemann, J., Dittmar, 617 T., and Herndl, G.J. (2019) Ammonia-oxidizing archaea release a suite of organic 
compounds potentially fueling prokaryotic heterotrophy in the ocean. Environ

619

Microbiol 21: 4062-4075.

620

Benitez-Nelson, C., and Buesseler, K.O. (1999) Variability of inorganic and organic

621 phosphorus turnover rates in the coastal ocean. Nature 398: 502-505.

622 Benner, R., and Strom, M. (1993) A critical evaluation of the analytical blank

623 associated with DOC measurements by high-temperature catalytic oxidation. Marine

624 Chemistry 41: 153-160.

625 Callahan, B.J., McMurdie, P.J., Rosen, M.J., Han, A.W., Johnson, A.J., and Holmes,

626 S.P. (2016) DADA2: High-resolution sample inference from Illumina amplicon data.

627 Nat Methods 13: 581-583.

628 Cammack, W.K.L., Kalff, J., Prairie, Y., and Smith, E.M. (2004) Fluorescent dissolved 629 organic matter in lakes: Relationships with heterotrophicmetabolism. Limnol Oceanogr

630 49: 2034-2045.

631 Carlson, C.A., Giorgio, P.A.d., and Herndl, G.J. (2007) Microbes and the Dissipation of

632 Energy and Respiration: From Cells to Ecosystems. Oceanography 20: 89-100.

633 Catalá, T.S., Reche, I., Fuentes-Lema, A., Romera-Castillo, C., Nieto-Cid, M., Ortega-

634 Retuerta, E. et al. (2015) Turnover time of fluorescent dissolved organic matter in the 635 dark global ocean. Nat Commun 6: 5986.

636 Christie-Oleza, J.A., Pina-Villalonga, J.M., Bosch, R., Nogales, B., and Armengaud, J.

637 (2012) Comparative proteogenomics of twelve Roseobacter exoproteomes reveals

638 different adaptive strategies among these marine bacteria. Mol Cell Proteomics 11:

639 M111 013110.

640 Coble, P.G. (1996) Characterization of marine and terrestrial DOM in seawater using 641 excitation-emission matrix spectroscopy. Marine Chemistry 51: 325-346. 
642 Cotner, J.B., Ammerman, J.W., Peele, E.R., and Bentzen, E. (1997) Phosphorus-limited

643 bacterioplankton growth in the Sarcrasso Sea. Aquat Microb Ecol 13: 141-149.

644 del Giorgio, P.A., Bird, D.F., Prairie, Y.T., and Planas, D. (1996) Flow Cytometric

645 Determination of Bacterial Abundance in Lake Plankton with the Green Nucleic Acid

646 Stain SYTO 13. Limnology and Oceanography 41: 783-789.

647 delGiorgio, P., and Cole, J.J. (1998) Bacterial growth efficiency in natural aquatic

648 ecosystems. Annu Rev Ecol Syst 29: 503-541.

649 Eguchi, M., Ostrowski, M., Fegatella, F., Bowman, J., Nichols, D., Nishino, T., and

650 Cavicchioli, R. (2001) Sphingomonas alaskensis, Strain AF01: an abundant oligotrophic

651 ultramicrobacterium from the North Pacific. Appl Environ Microbiol 67.

652 Fegatella, F., Lim, J., Kjelleberg, S., and Cavicchioli, R. (1998) Implications of rRNA

653 Operon Copy Number and Ribosome Content in the Marine Oligotrophic

654 Ultramicrobacterium Sphingomonas sp. Strain RB2256. Appl Environ Microbiol 64:

$655 \quad 4433-4438$.

656 Goldman, J.C., Caron, D.A., and Dennett, M.R. (1987) Regulation of gross growth

657 efficiency and ammonium regeneration in bacteria by substrate c-n ratio. Limnology and

658 Oceanography 32: 1239-1252.

659 Goto, S., Tada, Y., Suzuki, K., and Yamashita, Y. (2017) Production and Reutilization

660 of Fluorescent Dissolved Organic Matter by a Marine Bacterial Strain, Alteromonas

661 macleodii. Front Microbiol 8: 507.

662 Gram, L., Grossart, H.P., Schlingloff, A., and Kiorboe, T. (2002) Possible quorum

663 sensing in marine snow bacteria: production of acylated homoserine lactones by

664 Roseobacter strains isolated from marine snow. Appl Environ Microbiol 68: 4111-4116. 
665 Holmes, R.M., Aminot, A., Kérouel, R., Hooker, B. A., and Peterson, B. J. (1999) A

666 simple and precise method for measuring ammo- nium in marine and freshwater 667 ecosystems. Can J Fish Aquat Sci 56: 1801-1808.

668 Hoppe, H.G. (1983) Signiticance of exoenzymatic activities in the ecology of brackish 669 water: measurements by means of methylumbelliferyl substrates. Mar Ecol Progr Ser 670 11: 299-308.

671 Humphrey, B., Kjelleberg, S., and Marshall, K.C. (1983) Responses of marine bacteria 672 under starvation conditions at a solid-water interface. Appl Environ Microbiol 45:4367347

674 Jiao, N., Herndl, G.J., Hansell, D.A., Benner, R., Kattner, G., Wilhelm, S.W. et al. 675 (2010) Microbial production of recalcitrant dissolved organic matter: long-term carbon 676 storage in the global ocean. Nature Reviews Microbiology 8: 593-599.

677 Kawasaki, N., and Benner, R. (2006) Bacterial release of dissolved organic matter 678 during cell growth and decline: Molecular origin and composition. Limnol Oceanogr 679 51: 2170-2180.

680 Kirchman, D., Knees, E., and Hodson, R. (1985) Leucine incorporation and its potential 681 as a measure of protein-synthesis by bacteria in natural aquatic systems. Applied and 682 Environmental Microbiology 49: 599-607.

683 Koedooder, C., Guéneuguès, A., Van Geersdaële, R., Vergé, V., Bouget, F.-Y., 684 Labreuche, Y. et al. (2018) The Role of the Glyoxylate Shunt in the Acclimation to Iron 685 Limitation in Marine Heterotrophic Bacteria. Frontiers in Marine Science 5.

686 Kramer, G.D., and Herndl, G.J. (2004) Photo- and bioreactivity of chromophoric 687 dissolved organic matter produced by marine bacterioplankton. Aquat Microb Ecol 36: 688 239-246. 
690 Repeta, D.J. (2013) Characterisation and dynamics of dissolved organic matter in the

691 Northwestern Mediterranean Sea. Progress in Oceanography 119: 78-89.

692 Lauro, F.M., McDougald, D., Thomas, T., Williams, T.J., Egan, S., Rice, S. et al.

693 (2009) The genomic basis of trophic strategy in marine bacteria. Proc Natl Acad Sci

694 USA 106.

695 Lechtenfeld, O.J., Hertkorn, N., Shen, Y., Witt, M., and Benner, R. (2015) Marine 696 sequestration of carbon in bacterial metabolites. Nat Commun $\mathbf{6}$.

697 Legendre, L., Rivkin, R.B., Weinbauer, M.G., Guidi, L., and Uitz, J. (2015) The 698 microbial carbon pump concept: Potential biogeochemical significance in the globally 699 changing ocean. Progress in Oceanography 134: 432-450.

700 Lønborg, C., Álvarez-Salgado, X.A., Davidson, K., and Miller, A.E.J. (2009)

701 Production of bioavailable and refractory dissolved organic matter by coastal

702 heterotrophic microbial populations. Estuarine, Coastal and Shelf Science 82: 682-688.

703 Matallana-Surget, S., Douki, T., Cavicchioli, R., and Joux, F. (2009) Remarkable

704 resistance to UVB of the marine bacterium Photobacterium angsutum explained by an 705 unexpected role of photolyase. Photochem Photobiol Sci 8: 1313-1320.

706 Myklestad, S.M., Skanoy, E., and Hestmann, S. (1997) A sensitive and rapid method for 707 analysis of dissolved mono- and polysaccharides in seawater. Marine Chemistry 56: $708 \quad 279-286$.

709 Nelson, C.E., and Wear, E.K. (2014) Microbial diversity and the lability of dissolved 710 organic carbon. Proc Natl Acad Sci U S A 111: 7166-7167.

711 Noriega-Ortega, B.E., Wienhausen, G., Mentges, A., Dittmar, T., Simon, M., and

712 Niggemann, J. (2019) Does the Chemodiversity of Bacterial Exometabolomes Sustain 713 the Chemodiversity of Marine Dissolved Organic Matter? Front Microbiol 10: 215. 
714 Ogawa, H., Amagai, Y., Koike, I., Kaiser, K., and Benner, R. (2001) Production of

715 Refractory Dissolved Organic Matter by Bacteria. Science 292: 917-920.

716 Ortega-Retuerta, E., Marrasé, C., Muñoz-Fernández, A., Sala, M.M., Simó, R., and

717 Gasol, J.M. (2018) Seasonal dynamics of transparent exopolymer particles (TEP) and

718 their drivers in the coastal NW Mediterranean Sea. Science of the Total Environment

719 631: 180-190.

720 Osterholz, H., Niggemann, J., Giebel, H.A., Simon, M., and Dittmar, T. (2015)

721 Inefficient microbial production of refractory dissolved organic matter in the ocean. Nat

722 Commun 6: 7422.

723 Parada, A.E., Needham, D.M., and Fuhrman, J.A. (2016) Every base matters: assessing

724 small subunit rRNA primers for marine microbiomes with mock communities, time

725 series and global field samples. Environ Microbiol 18: 1403-1414.

726 Pedler, B.E., Aluwihare, L.I., and Azam, F. (2014) Single bacterial strain capable of

727 significant contribution to carbon cycling in the surface ocean. Proc Natl Acad Sci US

$728 \quad A$ 111: 7202-7207.

729 Quast, C., Pruesse, E., Yilmaz, P., Gerken, J., Schweer, T., Yarza, P. et al. (2013) The

730 SILVA ribosomal RNA gene database project: improved data processing and web-

731 based tools. Nucleic Acids Res 41: D590-596.

732 Rochelle-Newall, E., and Fisher, T.R. (2002) Production of chromophoric dissolved

733 organic matter fluorescence in marine and estuarine environments: an investigation into

734 the role of phytoplankton. Marine Chemistry 77: 7-21.

735 Romano, S., Dittmar, T., Bondarev, V., Weber, R.J., Viant, M.R., and Schulz-Vogt, 736 H.N. (2014) Exo-metabolome of Pseudovibrio sp. FO-BEG1 analyzed by ultra-high

737 resolution mass spectrometry and the effect of phosphate limitation. PLoS One 9:

738 e96038. 
739 Romera-Castillo, C., Sarmento, H., Alvarez-Salgado, X.A., Gasol, J.M., and Marrase,

740 C. (2011) Net production and consumption of fluorescent colored dissolved organic

741 matter by natural bacterial assemblages growing on marine phytoplankton exudates.

742 Appl Environ Microbiol 77: 7490-7498.

743 Sala, M.M., Aparicio, F.L., Balagué, V., Boras, J.A., Borrull, E., Cardelús, C. et al.

744 (2016) Contrasting effects of ocean acidification on the microbial food web under

745 different trophic conditions. ICES Journal of Marine Science: Journal du Conseil 73:

$746 \quad 670-679$.

747 Sánchez-Pérez, E.D., Pujo-Pay, M., Ortega-Retuerta, E., Conan, P., Peters, F., and

748 Marrasé, C. (2020) Mismatched dynamics of dissolved organic carbon and

749 chromophoric dissolved organic matter in the coastal NW Mediterranean Sea. Science

750 of The Total Environment 746: 141190.

751 Shimotori, K., Watanabe, K., and Hama, T. (2012) Fluorescence characteristics of

752 humic-like fluorescent dissolved organic matter produced by various taxa of marine

753 bacteria. Aquatic Microbial Ecology 65: 249-260.

754 Smith, D.C., Simon, M., Alldredge, A.L., and Azam, F. (1992) Intense hydrolytic

755 enzyme-activity on marine aggregates and implications for rapid particle dissolution

$756 \quad$ Nature 359: 139-142.

757 Sosa, O.A., Repeta, D.J., DeLong, E.F., Ashkezari, M.D., and Karl, D.M. (2019)

758 Phosphate-limited ocean regions select for bacterial populations enriched in the carbon-

759 phosphorus lyase pathway for phosphonate degradation. Environ Microbiol 21: 2402-

7602414.

761 Stoderegger, K., and Herndl, G.J. (1998) Production and release of bacterial capsular

762 material and its subsequent utilization by marine bacterioplankton. Limnol Oceanogr

763 43: 877-884. 
764 Teeling, H., Fuchs, B.M., Becher, D., Klockow, C., Gardebrecht, A., Bennke, C.M. et

765

766

767

768

769

770

771

772

773

774

775946.

776

777

778

779

780 e0142690. 946.

781

782 Induced by a Phytoplankton Bloom. Science 336: 608-611.

Thingstad, T.F., Zweifel, U.L., and Rassoulzadegan, F. (1998) P limitation of heterotrophic bacteria and phytoplankton in the northwest Mediterranean. Limnol Oceanogr 43: 88-94.

Van Wambeke, F., Christaki, U., Giannakourou, A., Moutin, T., and Souvemerzoglou, K. (2002) Longitudinal and vertical trends of bacterial limitation by phosphorus and carbon in the Mediterranean Sea. Microbial Ecology 43: 119-133.

Watson, S.W., Novitsky, T.J., Quinby, H.L., and Valois, F.W. (1977 ) Determination of bacterial number and biomass in the marine environment. Appl Envir Microb 33: 940-

Yamashita, Y., and Tanoue, E. (2008) Production of bio-refractory fluorescent

dissolved organic matter in the ocean interior. Nature Geoscience 1: 579-582.

Zhang, Z., Chen, Y., Wang, R., Cai, R., Fu, Y., and Jiao, N. (2015) The Fate of Marine Bacterial Exopolysaccharide in Natural Marine Microbial Communities. PLoS One 10: ( 
Table 1. Overview of the biodegradation experiments: Incubation date, treatment abbreviations, dissolved organic matter (DOM) and heterotrophic prokaryote (HP) innocula sources. deep.n: Deep DOM-Deep HP. deep.p: P. angustum DOM -Deep HP surf.n: Surface DOM-Surface HP. surf.p: P. angustum DOM -Surface HP. ndom: Surface DOM-Surface HP. +gluc: Surface DOM+ glucose-Surface HP. pdom : $P$. angustum DOM -Surface HP. sdom: S. alaskensis DOM-Surface HP

\begin{tabular}{|c|c|c|c|c|c|c|c|}
\hline Experiment & Date & Treatment & $\begin{array}{c}\text { DOM Source } \\
(90 \% \text { vol })\end{array}$ & $\begin{array}{c}\text { HP } \\
\text { Innocula }\end{array}$ & $\begin{array}{c}\text { Abundance } \\
\text { DOC } \\
\text { Nuts. } \\
\text { FDOM } \\
\end{array}$ & Enzymes & $16 s$ \\
\hline \multirow[t]{2}{*}{$\begin{array}{c}\text { Open Sea- } \\
\text { March }\end{array}$} & $\begin{array}{c}29 \mathrm{Mar} \\
2018\end{array}$ & & & & $\sqrt{ }$ & & \\
\hline & & $\begin{array}{l}\text { deep.n } \\
\text { deep.p } \\
\text { surf.n } \\
\text { surf.p }\end{array}$ & $\begin{array}{c}500 \mathrm{~m} \\
\text { P. angustum } \\
5 \mathrm{~m} \\
\text { P. angustum }\end{array}$ & $\begin{array}{c}500 \mathrm{~m} \\
6 \\
5 \mathrm{~m} \\
، \\
\end{array}$ & & & \\
\hline \multirow[t]{2}{*}{$\begin{array}{c}\text { Coastal Sea- } \\
\text { April }\end{array}$} & $\begin{array}{c}10 \mathrm{Apr} \\
2018\end{array}$ & & & & $\sqrt{ }$ & $\sqrt{ }$ & \\
\hline & & $\begin{array}{l}\text { ndom } \\
\text { pdom } \\
\text { sdom }\end{array}$ & \begin{tabular}{l}
\multicolumn{1}{c}{$5 \mathrm{~m}$} \\
P. angustum \\
S. alaskensis
\end{tabular} & $\begin{array}{c}5 \mathrm{~m} \\
، \\
،\end{array}$ & & & \\
\hline \multirow[t]{3}{*}{$\begin{array}{c}\text { Coastal Sea- } \\
\text { December }\end{array}$} & $\begin{array}{c}12 \text { Dec } \\
2018\end{array}$ & & & & $\sqrt{ }$ & $\sqrt{ }$ & $\sqrt{ }$ \\
\hline & & $\begin{array}{l}\text { ndom } \\
+ \text { gluc }\end{array}$ & $\begin{array}{c}5 \mathrm{~m} \\
5 \mathrm{~m} \\
(+ \text { glucose })\end{array}$ & $5 \mathrm{~m}$ & & & \\
\hline & & $\begin{array}{l}\text { pdom } \\
\text { sdom }\end{array}$ & $\begin{array}{l}P . \text { angustum } \\
\text { S. alaskensis }\end{array}$ & "6 & & & \\
\hline
\end{tabular}


Table 2: Characteristics of bacterial-derived DOM (mean \pm standard deviation): percentage of initial DOC released as bacterial dissolved organic matter $(\% \mathrm{DOC})$, finalinitial $(\Delta)$ values of fluorescent DOM peaks C, M, A (all surrogates for humic-like DOM, x10 $0^{-3}$ Raman Units) and T (surrogate for protein-like DOM, x10 $0^{-3}$ Raman Units) and the ratio between Peaks $\mathrm{C}$ and $\mathrm{T}(\mathrm{C} / \mathrm{T}$, indicative of the prevalence of protein-like over humic-like DOM). p: Photobacterium angustum s: Sphingopyxis alaskensis. p 1 and p 2, and s 1 and s 2 refer to independent experiments (See Experimental Procedures

799

800 for details).

\begin{tabular}{lrrrr}
\hline Experiment & $\mathrm{p} 1$ & $\mathrm{p} \mathrm{2}$ & $\mathrm{s} 1$ & $\mathrm{~s} 2$ \\
\hline Date & $03 / 2018$ & $07 / 2018$ & $03 / 2018$ & $11 / 2018$ \\
\hline \%DOC & $22.2 \pm 10.6$ & $10.3 \pm 2.1$ & $6.3 \pm 7.1$ & $10.3 \pm 4.6$ \\
\hline$\Delta$ FDOM.C & $3.21 \pm 0.14$ & $2.47 \pm 0.12$ & $2.64 \pm 1.68$ & $5.72 \pm 0.19$ \\
$\Delta$ FDOM.M & $4.84 \pm 0.44$ & $2.79 \pm 0.18$ & $9.03 \pm 3.38$ & $12.88 \pm 0.02$ \\
$\Delta$ FDOM.A & $4.29 \pm 0.55$ & $5.43 \pm 0.41$ & $13.74 \pm 6.63$ & $16.36 \pm 0.52$ \\
$\Delta$ FDOM.T & $35.37 \pm 1.60$ & $33.29 \pm 1.4$ & $6.38 \pm 0.54$ & $11.37 \pm 0.70$ \\
C/T & $0.09 \pm 0.008$ & $0.07 \pm 0.006$ & $0.42 \pm 0.30$ & $0.50 \pm 0.06$ \\
\hline
\end{tabular}


803

804 
Table 4. Diversity indexes: Richness, Evenness and Shannon for every treatment of the 806 Biodegradation experiment 3

\begin{tabular}{lllllll}
\hline & \multicolumn{2}{l}{ Richness } & Evenness & \multicolumn{3}{l}{ Shannon } \\
\hline Treatment & mean & SD & mean & SD & mean & SD \\
\hline Initial & 308 & & 0.86 & & 4.93 & \\
Surf HP- Surf DOM & 112 & 6 & 0.50 & 0.02 & 2.36 & 0.10 \\
Surf HP- Surf DOM+Gluc & 87 & 9 & 0.44 & 0.04 & 1.98 & 0.16 \\
Surf HP- P. angustum DOM & 81 & 10 & 0.59 & 0.03 & 2.60 & 0.16 \\
Surf HP- S. alaskensis DOM & 40 & 4 & 0.46 & 0.11 & 1.69 & 0.39 \\
\hline
\end{tabular}


813 Table 5: see horizontal Tables document

814 
Figure 1. Dissolved organic carbon (DOC, $\mu \mathrm{mol} \mathrm{L}{ }^{-1}$, dark grey columns) and glucose-C ( $\mu \mathrm{mol} \mathrm{C} \mathrm{L} \mathrm{L}^{-1}$, light grey columns) at the beginning (t0) and end (tf) of the growth experiments of each strain. Whiskers: Standard deviation; p1, p2: P. angustum s1, s2: $S$. alaskensis as described on Table 2.

Figure 2. Changes in prokaryotic heterotrophic abundance (PHA, cells $\mathrm{mL}^{-1}$ ) over incubation time in the three biodegradation experiments. Open sea-March (A): deep.n: deep water HP and DOM, deep.p: deep water HP, P. angustum DOM. surf.n: surface water HP and DOM, surface.p: surface water HP, P. angustum DOM. Coastal sea-April (B) and coastal sea-December (C): ndom: surface water HP and DOM; +gluc: surface water $\mathrm{HP}$ and $\mathrm{DOM},+20 \mu \mathrm{m} \mathrm{L}^{-1}$ glucose-C added. pdom: surface water HP, $P$. angustum DOM. sdom: surface water HP, $S$. alaskensis DOM. cont.p and cont.s: $P$. angustum and $S$. alaskensis DOM, no HP inoculum added

Figure 3. Prokaryotic Growth efficiency (PGE, \%) in the biodegradation experiments (Biodeg). Open Sea-March: deep.n: deep water HP and in situ DOM, deep.p: deep water HP, $P$ angustum DOM. surf.n: surface water HP and in situ DOM, deep.p: surface water HP, $P$ angustum DOM. Coastal sea experiments: ndom: surface water HP and in situ DOM; +gluc: surface water HP and DOM, $+20 \mu \mathrm{m} \mathrm{L}^{-1}$ glucose-C added. pdom: surface water HP, $P$. angustum DOM. sdom: surface water HP, S. alaskensis DOM

Figure 4. Changes in exoenzymatic activity over time in coastal biodegradation experiments (April: a, b, c, d. December: e, f, g, h). Columns: different study enzymes. Rows: Different experiments

Figure 5. Left panel: MDS plot of all treatments and replicates based on bray Curtis dissimilarity. Differences in prokaryotic community structure among treatments are significantly (ANOSIM test, $\mathrm{p}<0.05$ ). Right panel: Changes in prokaryotic community composition based in 16s rRNA Illumina sequencing in the coastal-December biodegradation experiment. Only orders having ASV's with a relative abundance higher than $2 \%$ are plotted. 
Table 3. Initial and final values of dissolved organic carbon (DOC) concentration ( $\left.\mu \mathrm{mol} \mathrm{L}^{-1}\right), \Delta \mathrm{DOC}$ per time $\left(\mu \mathrm{mol} \mathrm{L}^{-1} \mathrm{~h}^{-1}\right), \Delta \mathrm{DOC} / \mathrm{DOCt} 0(\%)$, $\triangle$ Biomass/DOC $(\%)$ and DOM fluorescence (protein-like peak T, humic-like peaks A, C and M, Raman Units) in all biodegradation experiments; tf: mean \pm SD of biological triplicates

\begin{tabular}{|c|c|c|c|c|c|c|c|c|c|c|c|c|c|}
\hline \multirow[b]{2}{*}{ Experiment-Treatment } & \multicolumn{2}{|r|}{ DOC } & \multirow[t]{2}{*}{$\Delta \mathrm{DOC} / \mathrm{t}$} & \multirow[t]{2}{*}{$\begin{array}{c}\Delta \text { Biomass/ } \\
\text { DOC (\%) }\end{array}$} & \multirow[t]{2}{*}{$\begin{array}{c}\Delta \mathrm{DOC} / \\
\operatorname{DOCt0}(\%) \\
\end{array}$} & \multicolumn{2}{|c|}{ FDOM.C } & \multicolumn{2}{|c|}{ FDOM.M } & \multicolumn{2}{|c|}{ FDOM.A } & \multicolumn{2}{|c|}{ FDOM.T } \\
\hline & to & tf & & & & to & tf & to & tf & to & tf & to & tf \\
\hline \multicolumn{14}{|l|}{ Open Sea-March } \\
\hline Deep HP- Deep DOM & 60.8 & $56.2 \pm 2.1$ & 0.04 & $8.4 \pm 0.5$ & 7.8 & 1.8 & 5.0 & 7.7 & 6.1 & 18.9 & 14.0 & 10.9 & 7.2 \\
\hline Deep HP- P. angustum DOM & 52.7 & $30.5 \pm 4.5$ & 0.18 & $4.9 \pm 1.6$ & 41.1 & 1.6 & 5.4 & 8.1 & 5.6 & 14.4 & 12.7 & 38.7 & 28.1 \\
\hline Surf HP- Surf DOM & 70.9 & $61.8 \pm 2.8$ & 0.08 & $4.0 \pm 1.3$ & 12.6 & 12.9 & 7.2 & 15.8 & 7.5 & 83.3 & 19.8 & 18.8 & 8.6 \\
\hline Surf HP- $P$. angustum DOM & 72.7 & $32.8 \pm 8.1$ & 0.33 & $1.4 \pm 0.3$ & 54.6 & 2.2 & 5.7 & 7.9 & 5.5 & 15.3 & 12.8 & 34.1 & 22.0 \\
\hline \multicolumn{14}{|l|}{ Coastal Sea-April } \\
\hline Surf HP- Surf DOM & 99.2 & $75.5 \pm 12.8$ & 0.16 & $3.3 \pm 1.1$ & 23.4 & 10.3 & 16.2 & 11.6 & 12.1 & 27.4 & 29.1 & 11.3 & 13.2 \\
\hline Surf HP- $P$. angustum DOM & 98.1 & $34.1 \pm 15.5$ & 0.45 & $2.0 \pm 0.2$ & 65.3 & 9.2 & 11.8 & 16.5 & 6.8 & 25.1 & 15.2 & 53.7 & 14.0 \\
\hline Surf HP- S. .alaskensis DOM & 76.0 & $57.0 \pm 4.1$ & 0.13 & $2.5 \pm 0.7$ & 25.0 & 16.5 & 21.9 & 32.3 & 17.1 & 41.2 & 16.9 & 16.5 & 14.4 \\
\hline \multicolumn{14}{|l|}{ Coastal Sea-December } \\
\hline Surf HP- Surf DOM & 83.0 & $74.1 \pm 2.3$ & 0.05 & $2.0 \pm 0.6$ & 10.8 & 11.2 & 11.2 & 12.1 & 12.5 & 28.4 & 29.2 & 14.3 & 11.2 \\
\hline Surf HP- Surf DOM+Gluc & 107.3 & $78.3 \pm 2.4$ & 0.18 & $1.9 \pm 0.2$ & 27.3 & 11.5 & 10.7 & 11.9 & 11.3 & 29.1 & 27.2 & 13.2 & 12.2 \\
\hline Surf HP- $P$. angustum DOM & 90.1 & $38.0 \pm 2.4$ & 0.31 & $9.2 \pm 3.4$ & 57.8 & 6.5 & 6.3 & 7.6 & 8.4 & 15.5 & 19.7 & 35.3 & 37.0 \\
\hline Surf HP- S. alaskensis DOM & 110.0 & $39.1 \pm 4.0$ & 0.43 & $6.4 \pm 1.7$ & 64.5 & 8.4 & 9.0 & 15.2 & 13.5 & 23.4 & 22.8 & 13.3 & 13.5 \\
\hline
\end{tabular}


Table 5. Review of previous estimates of dissolved organic matter (DOM) vs. biomass production by heterotrophic prokaryotes as percentage of the initial dissolved organic carbon (DOC) concentration

\begin{tabular}{|c|c|c|c|c|c|c|c|c|}
\hline Study & Substrate used & Procedence & $\begin{array}{l}\text { DOC Initial } \\
\left(\mu \mathrm{mol} \mathrm{L}^{-1}\right)\end{array}$ & $\begin{array}{l}\text { Time } \\
\text { (d) }\end{array}$ & $\begin{array}{l}\text { DOC final } \\
\left(\mu \mathrm{mol} \mathrm{L}^{-1}\right)\end{array}$ & $\begin{array}{l}\text { Biomass final } \\
\left(\mu \mathrm{mol} \mathrm{L}^{-1}\right)\end{array}$ & $\begin{array}{l}\text { \%DOC Released } \\
\text { as DOM }\end{array}$ & $\begin{array}{l}\text { \%DOC into } \\
\text { biomass }\end{array}$ \\
\hline (Ogawa et al., 2001) & Glucose & Coastal (Gulf of Mexico) & 208 & 2 & 30 & na & 15.0 & 7.0 \\
\hline \multirow[t]{2}{*}{ " } & Glutamate & Coastal (Sagami Bay) & 132 & 2 & 18 & na & 13.0 & 22.0 \\
\hline & Glucose & Coastal (North Sea) & 220 & 5 & 24 & 13.3 & 10.9 & 6.0 \\
\hline (Kawasaki and Benner, 2006) & Glucose & Lake (Murray) & 529 & 1 & 37 & 8 & 7.0 & 1.5 \\
\hline “ & Glucose & Coastal (Folly Beach) & 310 & 2 & 25 & 0.83 & 8.1 & 0.3 \\
\hline (Lønborg et al., 2009) & Glucose & Fjord (Loch Creran) & na & 30 & na & na & 11 & na \\
\hline (Koch et al., 2014) & Glucose & Antarctic & 326 & 21 & 45 & 30 & 13.8 & 9.2 \\
\hline (Lechtenfeld et al., 2015) & Glucose+Glutamic Acid & Coastal seawater & 283 & 1.5 & 10 & 6.7 & 3.5 & 2.4 \\
\hline (Arai et al., 2017) & Glucose & Coastal (Shizoka, Japan) & 833 & 5 & 60.4 & 272 & 7.3 & 32.4 \\
\hline \multicolumn{9}{|c|}{ Innocula from single bacterial strains } \\
\hline \multirow[t]{2}{*}{ (Romano et al., 2014) } & Glucose, $\mathrm{P}$ limited & Pseudovibrio sp. FO-BEG1 & 60000 & & na & 2000 & $0.9^{*}$ & 3.3 \\
\hline & Glucose, $\mathrm{P}$ replete & “ & & & & & $0.2^{*}$ & \\
\hline (Zhang et al., 2015) & Glucose & Alteromonas sp. JL2810 & 3333 & 5 & & & $8^{* *}$ & \\
\hline (Goto et al., 2017) & Glucose & Alteromonas macleodii & 995 & 1 & 58 & 6.1 & 5.8 & 0.6 \\
\hline (Noriega-Ortega et al., 2019) & Acetate & Phaeobacter inhibens & 70050 & na & 2400 & na & 3.4 & na \\
\hline \multirow[t]{2}{*}{ Present Study } & Glucose & Photobacterium angustum & 198 & & 55 & 15.4 & 16.3 & 4.4 \\
\hline & & Sphingopyxis alaskensis & 245 & 7 & 72 & 8.4 & 8.5 & 7.6 \\
\hline
\end{tabular}

bdl: below detection limit; na: not available (not measured or not reported in the paper)

Only SPE extractable fraction quantified ${ }^{* *}$ Only exopolysaccharide quantified 


Figure 1. Dissolved organic carbon (DOC, $\mu \mathrm{mol} \mathrm{L}{ }^{-1}$, dark grey columns) and glucose-C ( $\mu \mathrm{mol} \mathrm{C} \mathrm{L}^{-1}$, light grey columns) at the beginning (t0) and end (tf) of the growth experiments of each strain. Whiskers: Standard deviation; p1, p2: P. angustum s1, s2: $S$. alaskensis as described on Table 2.
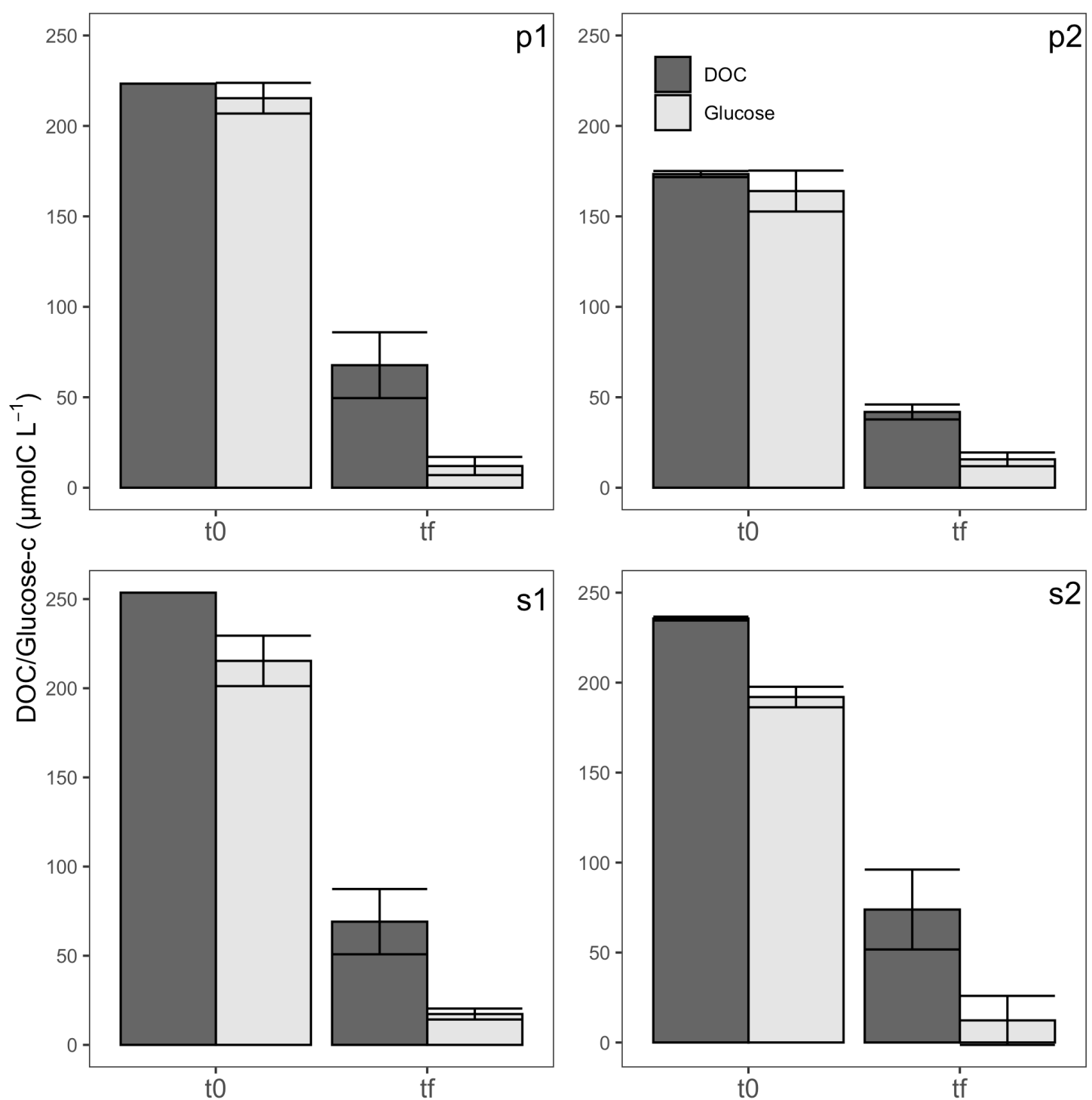
Figure 2. Changes in prokaryotic heterotrophic abundance (PHA, cells $\mathrm{mL}^{-1}$ ) over incubation time in the three biodegradation experiments. Open sea-March (A): deep.n: deep water HP and DOM, deep.p: deep water HP, P. angustum DOM. surf.n: surface water HP and DOM, surface.p: surface water HP, P. angustum DOM. Coastal sea-April (B) and coastal sea-December (C): ndom: surface water HP and DOM; +gluc: surface water HP and DOM, $+20 \mu \mathrm{m} \mathrm{L}^{-1}$ glucose-C added. pdom: surface water HP, P. angustum DOM. sdom: surface water HP, S. alaskensis DOM. cont.p and cont.s: P. angustum and S. alaskensis DOM, no HP inoculum added
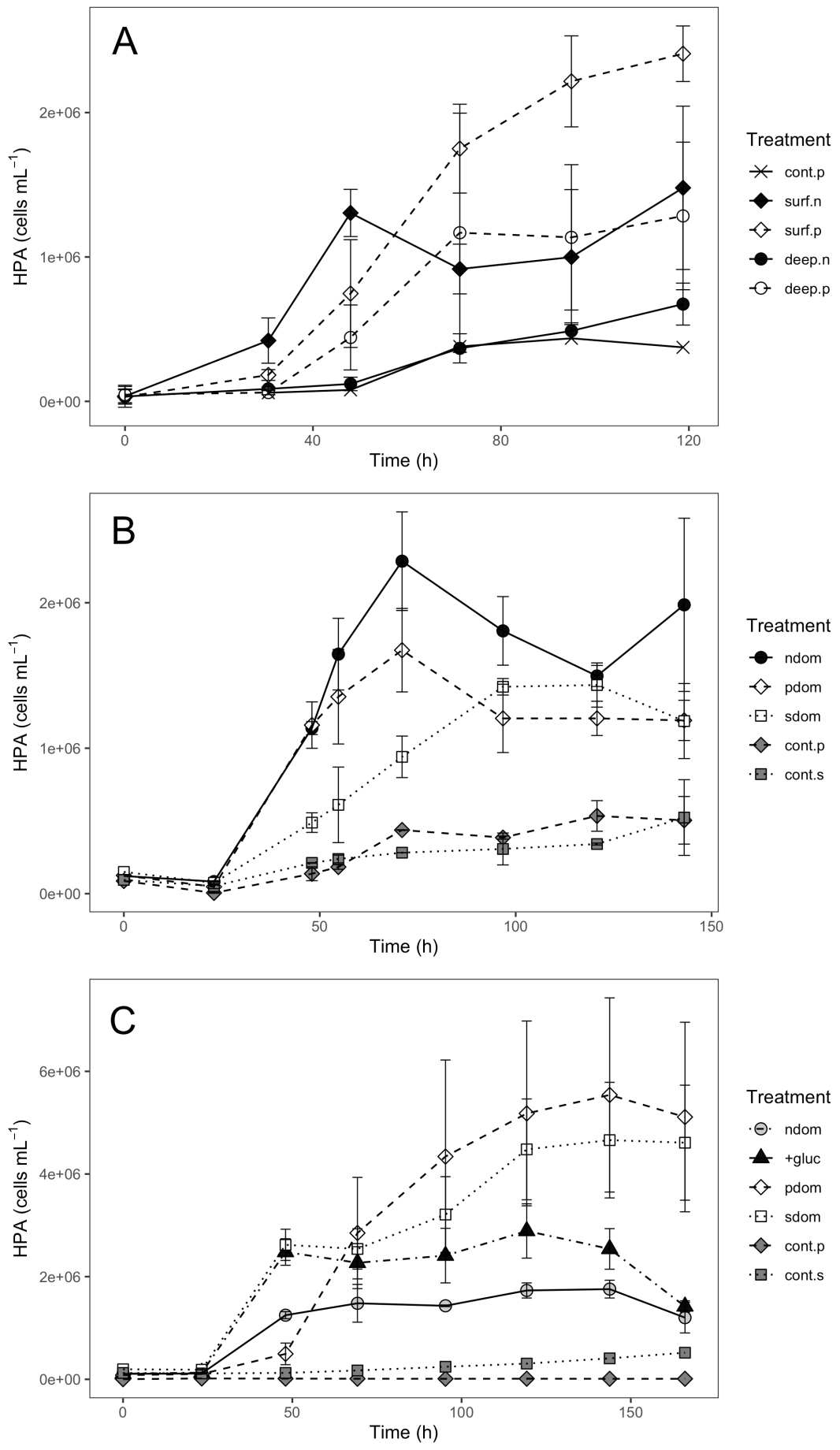
Figure 3. Prokaryotic Growth efficiency (PGE, \%) in the biodegradation experiments (Biodeg). Open Sea-March: deep.n: deep water HP and in situ DOM, deep.p: deep water HP, $P$ angustum DOM. surf.n: surface water HP and in situ DOM, deep.p: surface water HP, $P$ angustum DOM. Coastal sea experiments: ndom: surface water HP and in situ DOM; +gluc: surface water HP and DOM, $+20 \mu \mathrm{m} \mathrm{L}^{-1}$ glucose-C added. pdom: surface water HP, P. angustum DOM. sdom: surface water HP, S. alaskensis DOM
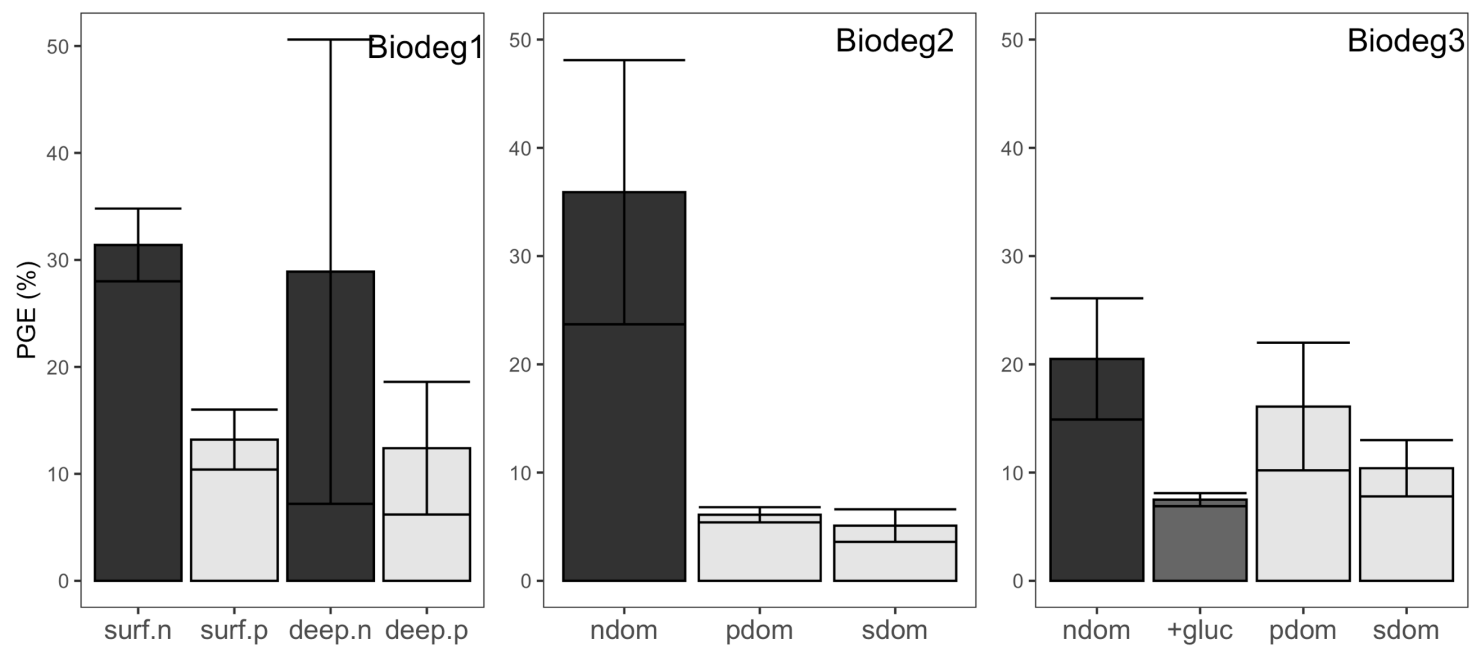
Figure 4. Changes in exoenzymatic activity over time in coastal biodegradation experiments (April: a, b, c, d. December: e, f, g, h). Columns: different study enzymes. Rows: Different experiments
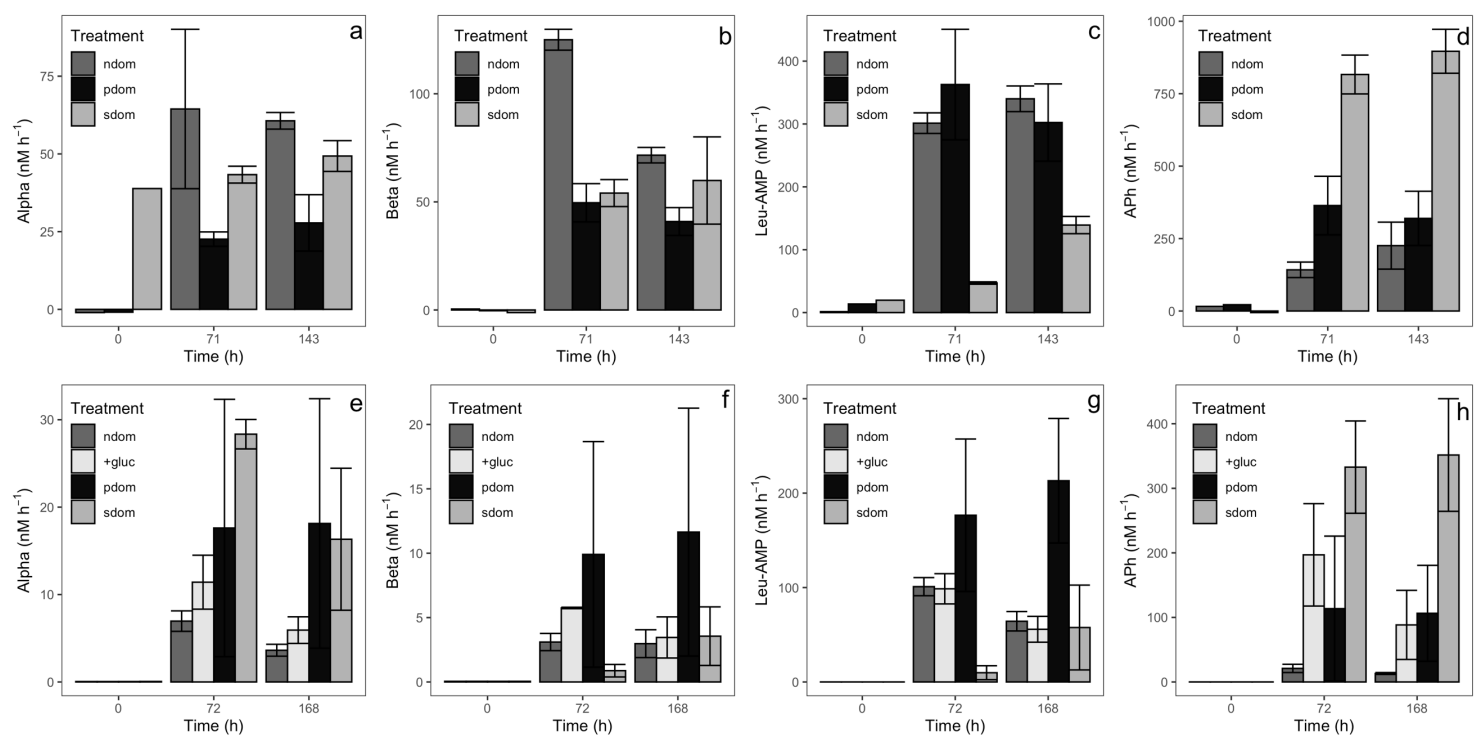
Figure 5. Left panel: MDS plot of all treatments and replicates based on bray Curtis dissimilarity. Differences in prokaryotic community structure among treatments are significantly (ANOSIM test, $\mathrm{p}<0.05$ ). Right panel: Changes in prokaryotic community composition based in 16s rRNA Illumina sequencing in the coastal-December biodegradation experiment. Only orders having ASV's with a relative abundance higher than $2 \%$ are plotted.

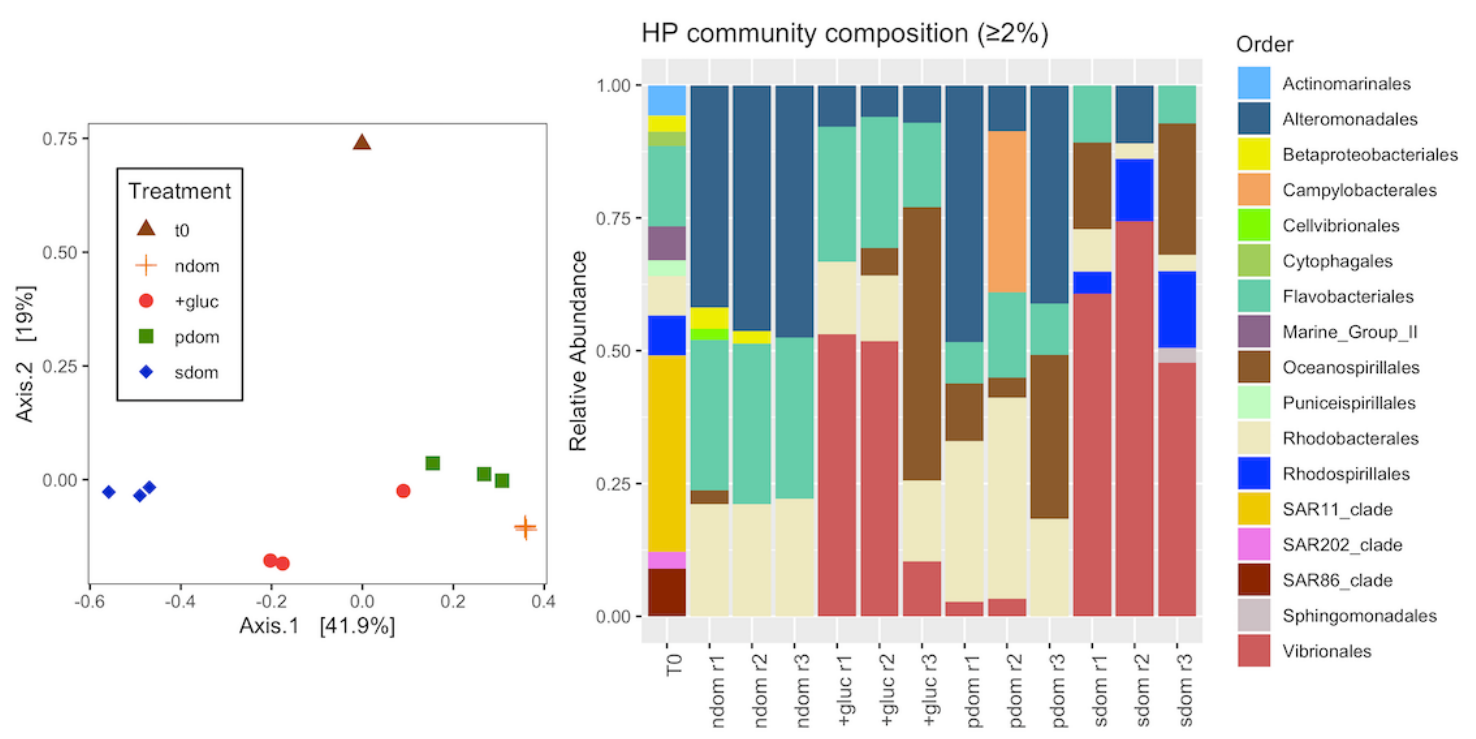


1 Supplementary Table 1 . Inorganic nutrients (phosphate, nitrate + nitrite, ammonium $2 \mu \mathrm{mol} \mathrm{L}^{-1}$ ) at the onset ( $\mathrm{t} 0$ ) and end (tf) of all strain incubations and biodegradation 3 experiments.

4

\begin{tabular}{|c|c|c|c|c|c|c|c|}
\hline Strain & Date & $\mathrm{PO}_{4}$ to & $\mathrm{PO}_{4} \mathrm{tf}$ & $\mathrm{NO}_{3} \mathrm{tO}$ & $\mathrm{NO}_{3}$ tf & $\mathrm{NH}_{4} \mathrm{to}$ & $\mathrm{NH}_{4} \mathrm{tf}$ \\
\hline S. alaskensis & mar-18 & 2.5 & 1.4 & 26 & 23.4 & 25 & 7.5 \\
\hline$"$ & nov-18 & 3.4 & 2.5 & 28 & 26.8 & 18.9 & 10.5 \\
\hline \multirow{2}{*}{$\begin{array}{r}\text { P. angustum } \\
"\end{array}$} & mar-18 & 2.8 & 1.4 & 19.9 & 20 & 20.3 & 7.1 \\
\hline & jul-18 & 2.8 & 1.4 & 23.8 & 23.3 & nd & nd \\
\hline Experiment & Treat & $\mathrm{PO}_{4} \mathrm{tO}$ & $\mathrm{PO}_{4} \mathrm{tf}$ & $\mathrm{NO}_{3} \mathrm{to}$ & $\mathrm{NO}_{3} \mathbf{t f}$ & $\mathrm{NH}_{4}$ to & $\mathrm{NH}_{4} \mathrm{tf}$ \\
\hline \multirow{4}{*}{$\begin{array}{r}\text { Open /March } \\
" \\
"\end{array}$} & deep.n & 1.3 & $1.23 \pm 0.1$ & 14.3 & $13.42 \pm 0.8$ & nd & $8.94 \pm 0.5$ \\
\hline & deep.p & 2.0 & $1.87 \pm 0.3$ & 27.6 & $24.8 \pm 2.3$ & 10.6 & $8.47 \pm 2.3$ \\
\hline & surf.n & 1.3 & $1.12 \pm 0.1$ & 13.5 & $11.60 \pm 0.2$ & 9.2 & $8.94 \pm 0.5$ \\
\hline & surf.p & 2.5 & $1.77 \pm 0.4$ & 28.2 & $27.91 \pm 4.2$ & 11.9 & $9.57 \pm 0.6$ \\
\hline \multirow{3}{*}{$\begin{array}{r}\text { Coastal/ April } \\
"\end{array}$} & ndom & 1.2 & $0.90 \pm 0.1$ & 12.1 & $11.33 \pm 0.2$ & nd & nd \\
\hline & pdom & 2.6 & $1.63 \pm 0.1$ & 26.7 & $25.13 \pm 0.5$ & nd & nd \\
\hline & sdom & 2.0 & $1.66 \pm 1.9$ & 31.7 & $29.79 \pm 0.4$ & nd & nd \\
\hline \multirow{4}{*}{$\begin{array}{r}\text { Coastal / Dec } \\
\text { " } \\
\text { " }\end{array}$} & ndom & 1.6 & $1.55 \pm 0.1$ & 9.3 & $8.62 \pm 0.1$ & 7.3 & $6.86 \pm 0.3$ \\
\hline & + gluc & 1.4 & $1.21 \pm 0.0$ & 9.9 & $9.43 \pm 0.2$ & 8.2 & $6.45 \pm 0.1$ \\
\hline & pdom & 2.5 & $2.03 \pm 0.1$ & 31.2 & $29.64 \pm 0.2$ & 14.6 & $12.57 \pm 0.4$ \\
\hline & sdom & 3.3 & $2.54 \pm 0.1$ & 32.6 & $30.53 \pm 0.5$ & 16.2 & $11.12 \pm 0.3$ \\
\hline
\end{tabular}

5 
6 Supplementary Figure 1. Changes in cell abundance in the strain growth experiments.

7 Symbols and whiskers are, respectively, averages and standard deviations of three

8 biological triplicates. Samples for DOM characterization were taken at the $\mathrm{t} 0$ and $\mathrm{t}$ final

9 points in each growth curve. Note the log-10 scale in the y axis

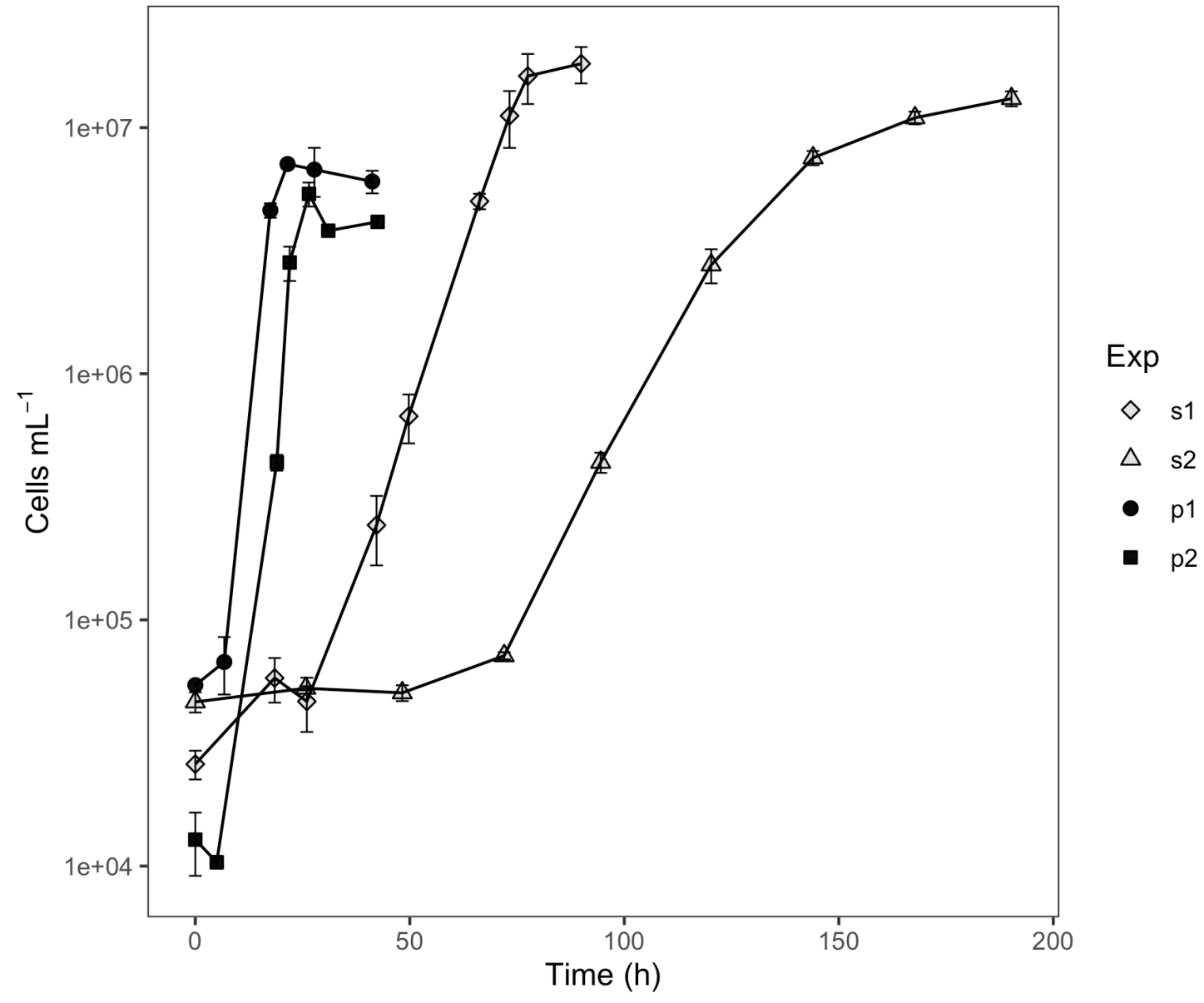


13 Supplementary Table 2. Results of the repeated measures ANOVA tests to compare 14 the changes in cell abundance over the different biodegradation experiments and 15 treatments. DFn: Degrees of freedom in the numerator. DFd: Degrees of freedom in the 16 denominator. F: F-value p: level of significance. ges: Generalized Eta-Squared measure 17 of effect size.

\begin{tabular}{llllll}
\hline \multicolumn{7}{c}{ Open Sea/March } \\
\hline Effect & DFn & DFd & F & p & ges \\
\hline treatment & 3 & 6 & 25.973 & 0.000778 & 0.806 \\
time & 4 & 8 & 58.986 & $5.63 \mathrm{E}-06$ & 0.806 \\
treat:time & 12 & 24 & 9.901 & $1.35 \mathrm{E}-06$ & 0.697 \\
\hline \multicolumn{5}{c}{ Coastal Sea/April } \\
\hline Effect & $\mathrm{DFn}$ & $\mathrm{DFd}$ & $\mathrm{F}$ & $\mathrm{p}$ & ges \\
\hline treatment & 2 & 4 & 12.73 & 0.018 & 0.649 \\
time & 6 & 12 & 75.287 & $8.04 \mathrm{E}-09$ & 0.877 \\
treat:time & 12 & 24 & 7.134 & $2.44 \mathrm{E}-05$ & 0.603 \\
\hline \multicolumn{7}{c}{ Coastal Sea/December } \\
\hline Effect & $\mathrm{DFn}$ & $\mathrm{DFd}$ & $\mathrm{F}$ & $\mathrm{p}$ & ges \\
\hline treatment & 3 & 6 & 7.242 & 0.02 & 0.602 \\
time & 6 & 12 & 67.137 & $1.56 \mathrm{E}-08$ & 0.729 \\
treat:time & 18 & 36 & 10.226 & $2.87 \mathrm{E}-09$ & 0.561 \\
\hline
\end{tabular}

18 
20 Supplementary Table 3. Results of pairwise t-tests between each treatment and time in 21 the three biodegradation experiments. Different letters denote significantly different 22 treatments at $\mathrm{p}<0.05$

23

\begin{tabular}{ccccc}
\hline \multicolumn{5}{c}{ Open Sea/March } \\
\hline Time/Treatment & deep.n & deep.p & surf.n & surf.p \\
\hline 1 & $\mathrm{a}$ & $\mathrm{a}$ & $\mathrm{b}$ & $\mathrm{c}$ \\
2 & $\mathrm{a}$ & $\mathrm{a}$ & $\mathrm{ab}$ & $\mathrm{b}$ \\
3 & $\mathrm{a}$ & $\mathrm{ac}$ & $\mathrm{b}$ & $\mathrm{c}$ \\
4 & $\mathrm{a}$ & $\mathrm{a}$ & $\mathrm{a}$ & $\mathrm{b}$ \\
5 & $\mathrm{a}$ & $\mathrm{ab}$ & $\mathrm{ab}$ & $\mathrm{b}$ \\
\hline \multicolumn{5}{c}{ Coastal Sea/April } \\
\hline Time/Treatment & ndom & pdom & sdom \\
\hline 1 & $\mathrm{a}$ & $\mathrm{b}$ & $\mathrm{ab}$ \\
2 & $\mathrm{a}$ & $\mathrm{a}$ & $\mathrm{b}$ & \\
3 & $\mathrm{a}$ & $\mathrm{ab}$ & $\mathrm{b}$ & \\
4 & $\mathrm{a}$ & $\mathrm{ab}$ & $\mathrm{b}$ & \\
5 & $\mathrm{a}$ & $\mathrm{a}$ & $\mathrm{a}$ & \\
6 & $\mathrm{a}$ & $\mathrm{b}$ & $\mathrm{ab}$ & \\
7 & $\mathrm{a}$ & $\mathrm{a}$ & $\mathrm{a}$ & \\
\hline \multicolumn{5}{c}{ Coastal Sea/December } \\
\hline Time/Treatment & ndom & gluc & pdom & sdom \\
\hline 1 & $\mathrm{a}$ & $\mathrm{b}$ & $\mathrm{c}$ & $\mathrm{d}$ \\
2 & $\mathrm{a}$ & $\mathrm{b}$ & $\mathrm{c}$ & $\mathrm{b}$ \\
3 & $\mathrm{a}$ & $\mathrm{b}$ & $\mathrm{ab}$ & $\mathrm{ab}$ \\
4 & $\mathrm{a}$ & $\mathrm{ab}$ & $\mathrm{ab}$ & $\mathrm{b}$ \\
5 & $\mathrm{a}$ & $\mathrm{b}$ & $\mathrm{abc}$ & $\mathrm{c}$ \\
6 & $\mathrm{a}$ & $\mathrm{a}$ & $\mathrm{ab}$ & $\mathrm{b}$ \\
7 & $\mathrm{a}$ & $\mathrm{ab}$ & $\mathrm{bc}$ & $\mathrm{c}$ \\
\hline \multicolumn{5}{c}{}
\end{tabular}


26 Supplementary Table 4. Composition of the minimum media used for strain growth

\begin{tabular}{|c|c|}
\hline Sea Salts & Final Concentration $\left(\mathrm{g} \mathrm{L}^{-1}\right)$ \\
\hline $\mathrm{NaCl}$ & 24 \\
\hline $\mathrm{Na}_{2} \mathrm{SO}_{4}$ & 4 \\
\hline $\mathrm{KCl}$ & 0.68 \\
\hline $\mathrm{KBr}$ & 0.1 \\
\hline $\mathrm{H}_{3} \mathrm{BO}_{3}$ & 0.025 \\
\hline $\mathrm{NaF}$ & 0.002 \\
\hline $\mathrm{MgCl}_{2} \cdot 6 \mathrm{H}_{2} \mathrm{O}$ & 10.8 \\
\hline $\mathrm{CaCl}_{2} \cdot 2 \mathrm{H}_{2} \mathrm{O}$ & 1.5 \\
\hline $\mathrm{SrCl}_{2} \cdot 6 \mathrm{H}_{2} \mathrm{O}$ & 0.024 \\
\hline $\mathrm{NaHCO}_{3}$ & 0.2 \\
\hline Macronutrients & Final Concentration $(\mu \mathrm{M})$ \\
\hline Glucose & $33 \mu \mathrm{M}(=200 \mu \mathrm{M} \mathrm{C})$ \\
\hline $\mathrm{NaNO}_{3}$ & $22 \mu \mathrm{M} \mathrm{N}$ \\
\hline $\mathrm{NH}_{4} \mathrm{Cl}$ & $22 \mu \mathrm{M} \mathrm{N}$ \\
\hline $\mathrm{NaHPO}_{4}$ & $4.4 \mu \mathrm{M} \mathrm{P}$ \\
\hline Trace Metals & Final Concentration $\left(\mu \mathrm{g} \mathrm{L}^{-1}\right)$ \\
\hline $\mathrm{CuCl}_{2} \cdot 2 \mathrm{H}_{2} \mathrm{O}$ & 0.015 \\
\hline $\mathrm{NiCl}_{2} \cdot \mathrm{H}_{2} \mathrm{O}$ & 0.025 \\
\hline $\mathrm{Na}_{2} \mathrm{MOO}_{4} \cdot 2 \mathrm{H}_{2} \mathrm{O}$ & 0.025 \\
\hline $\mathrm{ZnSO}_{4} .7 \mathrm{H}_{2} \mathrm{O}$ & 0.07 \\
\hline $\mathrm{MnCl}_{2} \cdot 4 \mathrm{H}_{2} \mathrm{O}$ & 0.1 \\
\hline $\mathrm{CoCl}_{2} \cdot 6 \mathrm{H}_{2} \mathrm{O}$ & 0.12 \\
\hline $\mathrm{FeCl}_{3} \cdot 6 \mathrm{H}_{2} \mathrm{O}$ & 4 \\
\hline EDTA & $2(0.068 \mu \mathrm{M} \mathrm{C})$ \\
\hline Vitamins & Final Concentration $\left(\mu \mathrm{g} \mathrm{L}^{-1} / \mu \mathrm{M}\right)$ \\
\hline P-aminobenzoic acid & $0.05 / 2.6$ \\
\hline D-biotin & $0.02 / 0.8$ \\
\hline Folic Acid & $0.02 / 0.9$ \\
\hline Niacinamide & $0.02 / 0.9$ \\
\hline D-pantothenic acid & $0.05 / 1.8$ \\
\hline Pyridoxal & $0.02 / 0.8$ \\
\hline Pyridoxamine & $0.10 / 3.3$ \\
\hline Pyridoxine & $0.10 / 3.9$ \\
\hline Riboflavin & $0.05 / 2.3$ \\
\hline Thiamine & $0.02 / 0.9$ \\
\hline D L-6,8-thioctic acid & $0.02 / 0.7$ \\
\hline Vitamin B12 & $0.05 / 2.3$ \\
\hline Nicotinamide & $0.05 / 2.5$ \\
\hline
\end{tabular}

